\title{
The Transformation in the Conception of Property in American Law, 1780-1860
}

\author{
Morton J. Horwitz†
}

The productive development of land and natural resources at the beginning of the nineteenth century drew into question many legal doctrines formulated in an agrarian economy. In the eighteenth century, the right to property had been the right to absolute dominion over land, and absolute dominion, it was assumed, conferred on an owner the power to prevent any use of his neighbor's land that conflicted with his own quiet enjoyment. ${ }^{1}$ Blackstone, in fact, asserted that even an otherwise lawful use of one's property could be enjoined if it caused injury to the land of another, "for it is incumbent on a neighboring owner to find some other place to do that act, where it will be less offensive."2 Not until the nineteenth century did it become clear that, because this conception of ownership necessarily circumscribed the rights of others to develop their land, it was, in fact, incompatible with a commitment to absolute dominion. Logical difficulties had been easily concealed by experience, since the prevailing ideal of absolute property rights arose in a society in which a low level of economic activity made conflicts over land use extremely rare. As the spirit of economic development began to take hold of American society in the early years of the nineteenth century, however, the idea of property underwent a fundamental transformation-from a static agrarian conception entitling an owner to undisturbed enjoyment, to a dynamic, instrumental, and more abstract view of property that emphasized the newly paramount virtues of productive use and development. By the time of the Civil War, the basic change in legal conceptions about property was completed. This article examines the process by which the change took place.

$\dagger$ Assistant Professor of Law, Harvard Law School.

1 For Blackstone, the right of property consisted of "that sole and despotic dominion which one man claims and exercises over the external things of the world, in total exclusion of the right of any other individual in the universe." $2 \mathrm{~W}$. Blackstone, ComMENTARIES *2.

23 id. at $* 217-18$. 


\section{Property Rights in the Nineteenth Century: The General View}

Two potentially contradictory theories of property rights underlay eighteenth century legal doctrines for resolving conflicts over uses of property. The first, an explicitly antidevelopmental theory, limited property owners to what courts regarded as the "natural" uses of their land, and often "natural" was equated with "agrarian." For example, in cases involving the conflicting claims of two riparian owners, courts usually gave precedence to appropriation of water not only for domestic purposes but often for agriculture and husbandry as well. ${ }^{8}$

Natural uses of land were probably favored also by strict liability in tort: any interference with the property of another gave rise to liability; only the lowest common denominator of noninjurious activity could avoid a suit for damages. The frequency with which eighteenth century courts solemnly invoked the maxim sic utere tuo, ut alienum non laedast is a significant measure of their willingness to impose liability for injury caused by any but the most traditional activities.

The second theory of property rights on which courts drew in the eighteenth century, though it appeared in a variety of legal forms, amounted to a rule that priority of development conferred a right to arrest a future conflicting use. Sometimes this rule was simply stated by the long-standing maxim "first in time is first in right." More refined formulations required that the first user be engaged in his activity for a period of time sufficient to ripen into a prescriptive property right against interfering activities.

At first glance, the rule of priority seems more compatible with economic development, since it gives at least the first user freedom to develop his land as he wishes. By contrast, doctrines based on natural use confer on all landowners equal power to maintain the traditional order of things and thereby to impose a continuing pattern of nondevelopment. Before the nineteenth century, however, the theory of propriety was harnessed to the common antidevelopmental end. Where two neighboring parcels of land were underdeveloped, each owner could claim a right, based on priority, to prevent further development. Thus, depending on the level of economic development from which one begins to measure priority, the consequences of the theories of natural and prior use may be the same; since the lowest level of development is also the earliest, each party acquires a prior right to the land in its natural state.

3 See Bohlen, The Rule in Rylands v. Fletcher, 59 U. PA. L. REv. 298 (1911).

4 Use your own [property] so as not to harm another's. 
Furthermore, just as the theory of priority could be reduced to one of natural use, so could the natural use doctrine claim to enforce a rule of priority. If the starting point for judgment is not the first introduction of a new use on the land but rather the prior state of inactivity before the new use appears, then once again the doctrines of priority and natural use yield the same result. Indeed, when in the name of economic development the inevitable attack on eighteenth century property doctrine begins, these two are regularly lumped together by their opponents as parts of one theory.

Though the two theories can be merged, they can also be made to have profoundly different consequences. If priority is measured not from a common denominator of natural use but from the time that a new technology appears, the theory of natural use continues to enforce its antidevelopmental premises, but a rule of priority now confers an exclusive property right on the first developer.

The potential for conflict between the two theories first began to surface in the nineteenth century. There are, for example, no cases before then dealing with conflicts over use of water in which an English or American court acknowledges that different consequences follow from a rule of "natural flow" as opposed to one of "prior appropriation." Courts were induced to distinguish between the two rules in such cases only when the judges began trying to break away from the antidevelopmental consequences of common law doctrine.

Once priority and natural use had taken on different operational meanings, the common law had moved into the utilitarian world of economic efficiency. Claims founded on natural use began to recede into a dim preindustrial past and the newer "balancing test" of efficiency came into sharp focus. As priority came to take on a life of its own distinct from doctrines of natural use, it was put forth not as a defense against encroachments of modernity but as an offensive doctrine justified by its power to promote economic development. In a capitalscarce economy, its proponents urged, the first entrant takes the greatest risks; without the recognition of a property right in the first developer -and a concomitant power to exclude subsequent entrants-there cannot exist the legal and economic certainty necessary to induce investors into a high-risk enterprise.

Though the strength of its hold varied among particular areas of the law, in general, priority became the dominant doctrine of property in the early stages of American economic growth. Its development paralleled that of pervasive state-promoted mercantilism in the early nineteenth century American economies; while it was displaced almost 
immediately in some areas of the law, in others it continued to stand firm well into the century.

The attack on the rule of priority reveals the basic instability of utilitarian theories of property. As property rights came to be justified by their efficacy in promoting economic growth, they also became increasingly vulnerable to the efficiency claims of newer competing forms of property. Thus, the rule of priority, wearing the mantle of economic development, at first triumphed over natural use. In turn, those property rights acquired on the basis of priority were soon challenged under a balancing test or "reasonable use" doctrine that sought to define the extent to which newer forms of property might injure the old with impunity. Priority then claimed the status of natural right, but only rarely did it check the march of efficiency. Nor could a doctrine of reasonable use long protect those who advanced under its banner since its function was to clear the path for the new and the efficient. Some of its beneficiaries eventually reclaimed the doctrine of priority, this time asserting the efficiency of "natural monopoly" and the inevitability of a standard of priority.

Viewed retrospectively, one is tempted to see a Machiavellian hand in this process. How better to develop an economy than initially to provide the first developers with guarantees against future competitive injury? And once development has reached a certain level, can the claims of still greater efficiency through competition be denied? By changing the rules, and disguising the changes in the complexities of technical legal doctrine, the facade of economic security can be maintained even as new property is allowed to sweep away the old.

The plan that the historian sees in retrospect, however, was not what the participants in this process saw. They were simply guided by the conception of efficiency prevailing at the moment. Practical men, they may never have stopped to reflect on the changes they were bringing about, nor on the vast differences between their own assumptions and those of their predecessors.

\section{Water Rights and Economic Development}

The extensive construction of mills and dams at the end of the eighteenth and beginning of the nineteenth centuries gave rise to the first important legal questions bearing on the relationship of property law to private economic development, and it was here that the antidevelopmental doctrines of the common law first clashed with the spirit of economic improvement. ${ }^{5}$ As a result, the evolving law of water rights

5 Though there had been controversies involving diversion of water for irrigation or 
had a greater impact than any other branch of law on the effort to adapt private law doctrines to the movement for economic growth.

Most of the legal controversies over water rights were of three types. The first, and by far the most important, involved an action by a downstream riparian landowner against his upstream neighbor, either for diverting the stream for agricultural purposes or for obstructing the natural flow of water in order to raise an upstream mill dam. As dams grew larger, a second set of cases dealt with the suit of an upstream mill owner against the downstream mill owner for throwing the water back so far as to impede the wheels or impair the fall of the upper mill. In a third group of cases, arising under the mill acts passed by most states, a neighboring landowner sued the proprietor of a mill who had flooded his land by raising a dam. Since the far-reaching impact of the mill acts is discussed later in this article, ${ }^{\theta}$ the discussion here will focus on the widespread changes in the rules regulating the exploitation of water resources during the first half of the nineteenth century. This branch of law is important not only because of its direct influence on the course of early economic growth but also because the problems it was forced to confront and the legal categories developed for dealing with them reveal the basic structure of thought about all forms of property in the nineteenth century.

\section{A. "Without diminution or obstruction"}

Two basic assumptions determined the approach of the common law to conflicts over water rights. First, since the flow of water in its natural channel was part of nature's plan, any interference with this flow was an "artificial," and therefore impermissible, attempt to change the natural order of things. Second, since the right to the flow of a stream was derived from the ownership of adjacent land, any use of water that conflicted with the interests of any other proprietor on the stream was an unlawful invasion of his property. A late eighteenth century New Jersey case clearly expressed the prevailing conception:

In general it may be observed, when a man purchases a piece of land through which a natural water-course flows, he has a right to make use of it in its natural state, but not to stop or divert it to the prejudice of another. Aqua currit, et debet currere is the language of the law. The water flows in its natural channel, and ought always to be permitted to run there, so that all through whose land it pursues its natural course, may continue to enjoy

saw and grist mills in the colonial period, the rise of large New England cotton mills after 1815 intensified the conflict.

6 See text and notes at notes 72-109 infra. 
the privilege of using it for their own purposes. It cannot legally be diverted from its course without the consent of all who have an interest in it. . . . I should think a jury right in giving almost any valuation which the party thus injured should think proper to afix to it. ${ }^{7}$

The premise underlying the law as stated was that land was not essentially an instrumental good or a productive asset but rather a private estate to be enjoyed for its own sake. The great English gentry, who had played a cental role in shaping the common law conception of land, regarded the right to quiet enjoyment as the basic attribute of dominion over property. Thus, the New Jersey court regarded the legitimate uses of water as those that served domestic purposes and husbandry, requiring insignificant appropriations of the water's flow. All other interferences with the natural flow of water, including both diversion and obstruction, were illegal "without the consent of all who have an interest in it." Exploitation of water resources for irrigation or mill dams, which necessarily required significant interference with the natural flow of water, was thus limited to the lowest common denominator of noninjurious development, just as conflicts over the use of land were invariably resolved in favor of economic inactivity.

When American judges first attempted to resolve the tension between the need for economic development and the fundamentally antidevelopmental premises of the common law, the whole system of traditional rules was threatened with disintegration. Some courts went so far as virtually to refuse to recognize any right to prevent interference with the flow of water to a mill. Connecticut courts, for example, for awhile limited the lower proprietor to the rights to prevent waste and to receive enough water to satisfy "necessary purposes."8 And, even after discarding this doctrine in 1818, Connecticut jurists continued to disagree over whether a right to water was based on the common law rule of natural flow or was gained only by a long-standing pattern of appropriation. ${ }^{\circ}$ The Supreme Judicial Court of Massachusetts in Shorey

7 Merritt v. Parker, 1 N.J.L. 526, 530 (Sup. Ct. 1795), See also Beissell v. Sholl, 4 Dall. 211 (Pa. 1800); Livezay v. Gorgas (Pa. 1811), in H. BRACKENRIDGE, LAW MISCELlANIES 454-56, (1814).

8 Perkins v. Dow, I Root 535 (1793), citing Howard v. Mason (1783). "If I can dispose of, and absorb upon my land, the whole of the stream excepting a sufficiency for necessary purposes," a legal commentator explained, "I have the prior right, because I am above him on the stream and have the first opportunity." $2 \mathrm{Z}$. SWLrT, A SYSTEM of THE LAws of the State of Connecticut 86 (1796). This rule did not, of course, express a theory of prior appropriation since, regardless of who first occupied the stream, the upper proprietor was granted "that artificial advantage which the situation of his ground will admit." Id. at 87. Indeed, it appears to be the only instance in American law of adoption of the pre-civil code French rule. See 3 J. Kent, Commentaries 439 n.(a) (4th ed. 1840).

( Ingraham v. Hutchinson, 2 Conn. 584, 591 (1818). Interestingly, the judge whose 
ข. Gorrell (1783) ${ }^{10}$ held that without long usage sufficient to confer a prescriptive right, there was no legal basis for preventing a newcomer from obstructing a stream. As a result, there were Massachusetts cases that denied any relief against even the substantial diversion of a stream for the purpose of irrigation. ${ }^{11}$ Although it appears that the Massachusetts courts soon succeeded in eroding the force of Shorey $v$. Gorrell by treating the plea in prescription as a mere matter of form, ${ }^{12}$ efforts to escape from the restrictive consequences of common law doctrines continued into the early nineteenth century as claims for relief against obstruction by upstream dams became more common. Some judges maintained that the common law action for diversion was simply not applicable to the temporary obstruction of water by upstream dams. ${ }^{13}$ Others sought to modify the common law definition of legal injury in order to permit extensive, uncompensated use of water for business purposes.

The most important challenge to the common law doctrine was the so-called reasonable use or balancing test. Though it did not ultimately prevail until the second quarter of the nineteenth century, a handful of decisions early in the century had already laid the ground for its eventual triumph. In the earliest case, Palmer $v$. Mulligan, ${ }^{14}$ a divided New York Supreme Court for the first time held that an upper riparian landowner could obstruct the flow of water for mill purposes. The common law action for interference with the flow of water, Judge Brockholst Livingston said, "must be restrained within reasonable bounds so as not to deprive a man of the enjoyment of his property." Courts, Livingston argued, must be prepared to ignore "little inconveniences" to other riparian proprietors resulting from obstruction of the natural flow. Otherwise, he reasoned: " $[\mathrm{H}] \mathrm{e}$ who could first build a dam or mill on any public or navigable river, would acquire an exclusive right, at least for some distance, whether he owned the con-

opinion overruled these eighteenth century decisions was Zephaniah Swift, whose System of Laws (1795) had justified those decisions. See note 8 supra.

10 W. Cushing, "Notes of Cases Decided in the Superior \& Supreme Judicial Courts of Massachusetts from 1772 to 1789." (Ms. Treasure Room, Harvard Law School).

11 Weston v. Alden, 8 Mass. 136 (1811); Bent v. Wheeler (Mass. 1800), in J. Sulurvan. The History of Land Titles in Massachusetts 273-74 (1801); 3 N. Dane, a General ABridgement and Digest of American LAW 16 (1824).

12 See text and note at note 52 infra.

13 Palmer v. Mulligan, 3 Cai. R. 307, 312 (N.Y. Sup. Ct. 1805) (Spencer, J.); Ingraham v. Hutchinson, 2 Conn. 584, 595 (1818) (Gould, J., dissenting). In Sherwood v. Burr, 4 Day 244 (1810), the Connecticut Supreme Court resorted to the doctrine of prescription to deal with the novel problem of downstream obstruction, thereby implying that without long use the upstream owner would have no right of action for obstruction.

143 Cai. R. 307, 313-14 (1805). 
tiguous banks or not; for it would not be easy to build a second dam or mound in the same river on the same side, unless at a considerable distance, without producing some mischief or detriment to the owner of the first."15

Palmer $v$. Mulligan represents the beginning of a gradual acceptance of the idea that the ownership of property implies above all the right to develop that property for business purposes. Livingston understood that a rule making all injuries from obstruction of water compensable would, in effect, confer an exclusive right of development on the downstream property. The result, he concluded, would be that "the public, whose advantage is always to be regarded, would be deprived of the benefit which always attends competition and rivalry." Again, in Platt $v$. Johnson, ${ }^{16}$ in which the court held in favor of an upstream mill owner whose dam occasionally detained the flow of water for a number of days, the court observed that the sacred common law maxim sic utere "must be taken and construed with an eye to the natural rights of all." The court revealed a fundamentally new outlook on the question of conflicting rights to property: "Although some conflict may be produced in the use and enjoyment of such rights, it cannot be considered, in judgment of law, an infringement of right. If it becomes less useful to one, in consequence of the enjoyment by another, it is by accident, and because it is dependent on the exercise of the equal rights of others." 17

These two cases marked a turning point in American legal development. ${ }^{18}$ Anticipating a widespread movement away from property theories of natural use and priority, they introduced into American common law the entirely novel view that an explicit consideration of the relative efficiencies of conflicting property uses should be the paramount test of what constitutes legally justifiable injury. As a consequence, private economic loss and judicially determined legal injury, which for centuries had been more or less congruent, began to diverge.

Change in common law doctrine, however, is rarely abrupt, especially when a major transformation in the meaning of property is involved. Common lawyers are more comfortable with a process of gradually giving new meanings to old formulas than with explicitly casting the old doctrines aside. Thus, it is not surprising that, in periods

15 Id. at 814.

1615 Johns. 213, 218 (N.Y. 1818).

17 Id. at 218.

18 Outside of New York, I have found only one other case before 1825 that followed the principle that diversion or obstruction of water might be justified by a doctrine of reasonable use which took account of a right to equal exploitation of water. Runnels $\mathrm{v}$. Bullen, 2 N.H. 532, 537 (1823). See also Merritt v. Brinkerhoff, 17 Johns. 306 (1820). 
of great conceptual tension, there emerges a treatise writer who tries to smooth over existing stresses in the law. Some such writers try to nudge legal doctrine forward by extracting from the existing conflict principles that are implicit but have not yet been expressed. Story's work in equity or commercial law comes to mind as an example. Others seek to banish novelty and to return the law to an earlier and simpler past. Joseph Angell was of the latter variety.

In his treatise, Watercourses, published in 1824, Angell reaffirmed the common law view that all diversion and obstruction of the natural flow of water was actionable. His only concession to a rule of equal or proportionate use was to observe that since the common law rules "are undoubtedly liable to a rational and liberal construction," they would not allow "a right of action for every trivial and insignificant deprivation."19 Although in Palmer $v$. Mulligan the New York court had attempted to justify its break with the past by showing that the injury to the lower mill owner was slight, Angell attacked the decision as "certainly contrary to the authorities, and obviously unjust." 20 In short, Angell's treatise asserted the traditional common law view that the only test for a reasonable use of water was the absence of all but the most trivial injury.

Though Angell sought to consolidate the past not a moment too early, his efforts hardly counted. The common law is especially cruel to those whom it casts aside. It either ignores them, soon forgetting that they ever existed, or, more usually, uses them as authority for propositions they did not accept. Angell's fate lay somewhere in between. In 1827, Justice Story wrote his influential opinion in Tyler $v$. Wilkinson, ${ }^{21}$ citing all manner of contradictory authority, including, of course, Angell's treatise. Thereafter, Story was taken to have merely restated Angell's position and the clear inflexibility of the latter's analysis was forever replaced by the soothing, oracular quality of Story's formulation. Whenever Angell is cited afterwards, though the words be his, the meaning is supplied by Story.

Story's opinion is the classically transitional judicial opinion, filled with ambiguities sufficient to make any future legal developments possible. ${ }^{22}$ It opens with a reaffirmation of traditional doctrine: the riparian owner "has a right to use of the water ... in its natural current,

19 WATERCourses 37 (1st ed. 1824).

$20 \mathrm{Id}$. at 41.

2124 F. Cas. 472 (No. 14,312) (C.C.D.R.I. 1827).

22 Professor Lauer correctly sees the "almost schizophrenic . . . . nature" of these early transitional water cases, which wavered between "both the pre-existent law and the need for just apportionment of the water." Lauer, Reflections on Riparianism, 35 Mo. L. REv. $1,8(1970)$. 
without dimunition or obstruction . . .."23 But even as he stated this principle, Story seemed to perceive its harsh antidevelopmental tendencies and he attempted to qualify its rigor. "I do not mean to be understood," he wrote, "as holding the doctrine that there can be no dimunition whatsoever, and no obstruction or impediment whatsover ... for that would be to deny any valuable use. ... The true test of the principle and extent of the use is, whether it is to the injury of the other proprietors or not." Some "dimunition in quantity, or a retardation or acceleration of the natural current" is permissible if it is "not positively and sensibly injurious ...."24

By insisting, after all, that the true test of the riparian doctrine was reasonable use, but that reasonableness meant simply the absence of injury, Story managed to finesse the pressing problem of determining the extent to which conflicting and injurious uses of property could be regulated in the interest of economic development. Despite his invocation of the reasonable use formula in Tyler, however, it is clear from later opinions ${ }^{25}$ that he, like Angell, wished to perpetuate the principle of natural flow. ${ }^{26}$

23 Story continued:

The consequence of this principle is, that no proprietor has a right to use the water to the prejudice of another. It is wholly immaterial, whether the party be a proprietor above or below, in the course of the river; the right being common to all the proprietors on the river, no one has a right to diminish the quantity which will, according to the natural current, flow to the proprietor below, or to throw it back upon a proprietor above.

$24 \mathrm{~F}$. Cas. at 474.

24 Id.

25 Though Tyler $v$. Wilkinson has often mistakenly been understood to expound a doctrine of proportionate use, I have found no subsequent case in which Story upheld any interference with the flow, unless based on prescriptive right as in Tyler itself. See Lauer, supra note 22 , at 8 . Indeed, Story often seemed routinely to apply a "natural flow" rule in granting injunctive relief. Farnum v. Blackstone Canal Corp., 8 F. Cas. 1059 (No. 4675 ) (C.C.D.R.I. 1830); Mann v. Wilkinson, 2 Sumner 273 (C.C.D.R.I. 1835). More illuminating still, in Webb v. Portland Mfg. Co., 29 F. Cas. 506 (No. 17,332) (C.C.D. Me. 1838), he found against a defendant who had extracted a proportionate part of the water from a stream for mill purposes even though there was no proof of actual damage. And in Whipple v. Cumberland Mfg. Co., 29 F. Cas 934 (No. 17,516) (C.C.D. Me. 1843), he upheld an action against a downstream mill owner for flowing back water, again without proof of actual injury to the plaintiff's mills. There was no need to prove damage, he wrote, since:

the principle of law goes much further; for every riparian proprietor is entitled to have the stream flow in its natural channel, as it has been accustomed to flow, without any obstruction by any mill or riparian proprietor below on the same stream .... And if any mill or riparian proprietor below on the same stream does ... undertake to obstruct or change the natural stream, then, although the riparian proprietor above cannot establish in proof, that he has suffered any substantial damage thereby, still he is entitled to recover nominal damages, as it is an invasion of his rights .....

Id. at 935-36. By allowing a damage action-and presumably an injunction-without proof of actual injury, Story went beyond the common law in restraining exploitation 
Tyler $v$. Wilkinson, which spawned a line of decisions opposed to all diversion or obstruction of water regardless of any beneficial consequences, ${ }^{27}$ marks the nineteenth century highpoint in articulating the traditional conception of property that had already come under attack. Not only did it express a preproductive view of property as entailing the right to undisturbed ownership free from all outside interference, but proceeding from eighteenth century conceptions of absolute property rights, it condemned all conflicting injurious uses of land without consideration of whether such exploitation would maximize total economic welfare.

Yet, by acknowledging that the utilitarian criterion of valuable use was the ultimate source of legal rules, Story's reasonable use standard became almost immediately an open-ended formula through which common law judges could implement their own conceptions of desirable social policy. As a result, Tyler $v$. Wilkinson is cited more often during the second quarter of the nineteenth century to support than to condemn the reasonableness of a mill's interference with the flow of water.

The effort to free property law of its antidevelopmental premises was still very much a struggle at mid-century. As late as 1852, Massachusetts Chief Justice Shaw still found it necessary to argue that the law did not bar all obstructions of a watercourse, "without dimunition, acceleration, or retardation of the natural current," else "no proprietor could have any beneficial use of the stream, without an encroachment on another's right . ..."28 By the time of the Civil War, however, most courts had come to recognize a balancing test, making "reasonable use"

\footnotetext{
of water resources. It was one thing to hold that economic development could not take place at another's expense, and quite another to allow an existing riparian owner to prevent exploitation of surplus water on the ground that he might use it at some future time. Not only was Story's formulation contrary to any supposed right of equal use; it also resulted in a rule still more monopolistic and exclusionary than anything the common law had required.

26 Contrast Story's views with those put forth by the Vermont court in the same year: "The common law of England seems to be that each land owner, through whose land a stream of water flows, has a right to the water in its natural course, and any diversion of the same to his injury, gives him a right of action. . . . Should this principle be adopted here, its effect would be to let the man who should first erect mills upon a small river or brook, control the whole and defeat all the mill privileges from his mills to the source." In the absence of "wanton waste" or "obstruction," it allowed the upstream proprietor to build a mill dam that would interfere with the natural flow of water. Martin v. Bigelow, 2 Aiken 184, 187 (Vt. 1827).

27 See, e.g., Omelvany v. Jaggers, 2 S.C. (Hill) 634 (1835); Buddington v. Bradley, 10 Conn. 213 (1834); Arnold v. Foot, 12 Wend. 330 (N.Y. Sup. Ct. 1834).

28 Elliot v. Fitchburg R.R., 64 Mass. (10 Cush.) 191, 195 (1852).
} 
of a stream "depend on the extent of detriment to the riparian proprietors below." 29

\section{B. "The usages and wants of the community"}

It is important to appreciate the central role that the refashioning of American water law to the needs of industrial development played in the more general transformation of the law of property in the nineteenth century. Between 1820 and 1831 the productive capacity of American cotton mills increased sixfold..$^{30}$ Joseph Angell noted that more cases on the subject of water rights had been decided in the years between 1824 and 1833, when the first and second editions of his Watercourses appeared, than during the entire previous history of the common law. ${ }^{31}$ Under the powerful influence of this rapid development, judges began to understand that the traditional rights of property entailed the power to exclude would-be competitors and that some injurious use of property was an inevitable consequence of any scheme of competitive economic development. They sought to free the idea of property from its exclusionary bias by enlarging the range of noncompensable injuries. The increasing frequency with which courts appealed to the idea of damnum absque injuria ${ }^{32}$ seems to have occurred in direct proportion to their recognition that conflicting and injurious uses of property were essential to economic improvement.

The most dramatic departure from common law riparian principles took place in Massachusetts, where, ever since the colonial mill acts, it had been the practice to confer privileges on mill owners in order to promote the growth of industry. As mills proliferated, a new set of technological considerations began to upset conventional legal doctrine. Since the amount of water power that a mill could generate depended largely on the fall of water, an increase in the height of a lower dam often reduced the fall of water from an upper dam. At the same time, the construction of large integrated cotton mills after 1815 unleashed such an enormous demand for water power that, as one observer noted in 1829, "in very many cases, only one of many proprietors can, in fact,

29 Snow v. Parsons, 28 vt. 459, 462 (1858). For a much earlier recognition of this principle, see Hoy v. Sterrett, 2 Watts 327, 332 ( $\mathrm{Pa}$. 1834), in which the court, though citing Tyler $v$. Wilkinson for the purpose of rejecting the plaintiff's claim to a right derived from prior occupancy, nevertheless held that if "the water was no longer detained than was necessary for a proper enjoyment of it ... for the use of [the defendant's] mill, it is damage to which the plaintiff must submit."

30 R. Foget, Railroads and American Economic Growth 123 (1964).

$31 \mathrm{~J}$. ANgeld, Watercourses vii (2d ed. 1833).

32 Damage without legal injury. 
improve a [stream] because the occupation of one mill site may render the others useless. Which proprietor shall, in such case, be preferred?" 33

Chief Justice Shaw pondered this question in Cary $v$. Daniels. ${ }^{34}$ "[O]ne of the beneficial uses of a watercourse," he began, "and in this country one of the most important, is its application to the working of mills and machinery; a use profitable to the owner, and beneficial to the public." Proceeding from this new utilitarian orthodoxy, Shaw stated a legal doctrine strikingly different from Story's earlier formulation. Not only did the law require "a like reasonable use by the other proprietors of land, on the same stream, above and below," but it also took account of the "usages and wants of the community" and "the progress of improvement in hydraulic works." It required that "no one can wholly destroy or divert" a stream so as to prevent the water from flowing to the proprietor below, nor "wholly obstruct it" to the disadvantage of the proprietor above. ${ }^{35}$ Thus, despite its invocation of "reasonable use," Shaw's formulation tended to erode a standard of proportionality: a mill owner who did not "wholly" obstruct a stream might claim that "the needs and wants of the community" justified his using more than a proportionate share of the water.

That Shaw intended this result is clear from Cary $v$. Daniels itself, in which the Chief Justice expressly rejected proportionality under the circumstances "growing out of the nature of the case." 36 Under manufacturing conditions then existing, he observed, beneficial uses of water were often, of necessity, mutually exclusive. Where the power needs of particular manufacturing establishments were such that maximum exploitation of limited water resources required a monopoly, " $[\mathrm{i}] \mathrm{t}$ seems to follow, as a necessary consequence from these principles, that ... . the proprietor who first erects his dam for such a purpose has a right to maintain it, as against the proprietors above and below; and to this extent, prior occupancy gives a prior title to such use."37

Shaw's opinion is premised on the desirability of maximizing economic development even at the cost of equal distribution. There was, of course, no reason why he could not have held that the permissible

33 The Law of Water Privileges, 2 AM. JuRisT 25, 27 (1829).

8449 Mass. (8 Met.) 466 (1844).

35 Id. at $476-77$.

$36 \mathrm{Id}$. at 477. In more conventional cases as well, Shaw's court often insisted that any use of water for manufacturing purposes was prima facie reasonable, regardless of proportionality. See, e.g., Pitts v. Lancaster Mills, 54 Mass. (13 Met.) 156 (1847), where a manufacturing company was held justified in obstructing a stream so long as "they detained the water no longer than was necessary to raise their own head of water and fill their own pond." Id. at 158. See also Hoy v. Sterrett, 2 Watts 327 (Pa. 1834).

3749 Mass. (8 Met.) at 477. 
limits of economic growth were reached at the point at which exploitation of water resources were equal, that large cotton mills had to pay their own way to the extent that their operation exceeded the limits of proportional appropriation. Indeed, judges could also have demanded, a half century earlier, that equality of use be achieved through compensation of existing riparian owners. In the nineteenth century, however, there were few limits to the dominant mentality of maximization. When proportionate use was regarded as more efficient than priority, proportionality became the standard of reasonable use. When, in turn, proportionality stood in the way of the efficient use of water resources, the law returned to priority as the standard of reasonable use.

As Cary v. Daniels demonstrated, the doctrine of reasonable use could assimilate its historic antagonist-the rule of priority-and thereby make monopoly reasonable once again. Once the question of reasonableness of use became a question of efficiency, legal doctrine enabled common law judges to choose the direction of American economic development. By the time of Cary v. Daniels, they were so captivated by the spirit of improvement that they were willing to manipulate the concept of property to conform to their own notions of the needs of industrialization. In the seventeen years after Tyler $v$. Wilkinson, the direction of the law had turned entirely around.

\section{Property Rights and Monopoly Power}

In this century there has been considerable discussion whether, before Tyler $v$. Wilkinson, the common law of water rights was a regime of riparian ownership or one based on principles of prior appropriation. ${ }^{38}$ As we have seen, however, it was only after judges in the early nineteenth century began to respond to the felt need to modify the common law doctrine of diversion as it applied to mills and dams that the theory of prior appropriation emerged as an independent factor in American water law. By mid-century it had outlived its usefulness and, along with the related law of prescription, was discarded.

A. "The benefit which always attends competition"

In their effects on economic development, the common law principle of natural flow and a rule of prior appropriation were at first indistinguishable. Early cases relied on the two theories as alternative

38 The latter system, which prevails in many western states today, confers on the earlier occupant of a stream the right to continue using water to the extent that he had before the arrival of a later occupant. Compare Wiel, Waters: American Law and French Authority, 33 HARv. L. REv. 133 (1919) with Maass \& Zobel, Anglo-American Water Law: Who Appropriated the Riparian Doctrine?, 10 Public PoLrcy 109 (1960). 
grounds for preventing the exploitation of water. ${ }^{39}$ Only when a millowner justified obstruction or diversion on the basis of prior appropriation, while the downstream plaintiff claimed a natural right to prevent all interference with the flow regardless of priority, could a choice between the two theories be of consequence. Indeed, it was only in the nineteenth century that a theory of priority was used offensively in order to maintain a right to obstruct the flow. ${ }^{40}$

39 The first modern English decision on water rights, Bealey v. Shaw, 6 East 208 (K.B. 1805), is typical. The court held that an upstream proprietor could not divert a greater proportion of a stream than he had a right to on the basis of long use. Of the four judges who sat, two seemed to think that the plaintiff should prevail because he had previously appropriated the portion of the stream at issue, while the other two arrived at the same result on the ground that the plaintiff was entitled to the flow as a natural right regardless of priority. See also Merritt v. Parker, I N.J.L. 526 (1795), which prevents upstream development by citing both theories.

40 In Massachusetts, however, an early departure from the common law tradition led to a rather complicated evolution of legal doctrine, resulting in the earliest consideration of a separate theory of prior appropriation. Most eighteenth century Massachusetts water cases proceeded from the theory that the sole basis for a right to the flow of water was a claim of prescription founded on immemorial usage. 3 N. DANE, supra note 11, at 14-17; J. Sulcrvan, supra note 11, at 272-74; 1 Legal Papers of John Adams 68 n.90, 82 n.108, (L. Wroth \& H. Zobel eds. 1965). But see Clark v. McCarney (1772), id. at 68, in which both parties appear to have been apportioned water privileges by a common grantor, and Pearson v. Tenny (1802), 3 N. DANE, supra note 11, at 14, in which a contractual relationship governed. I have also found one Massachusetts action for diversion in which the plaintiff prevailed though he asserted neither a prescriptive right nor a contractual agreement. Clark v. Billings (1783), cited in W. Cushing, supra note 10.

The theory that in the absence of agreement only prescription created a property interest in water was derived from a much older English rule that had been all but superseded by the first quarter of the seventeenth century, when English courts declared that the right to water was a "natural right" not founded on long usage. Shury v. Piggot, 3 BuIst. 339 (K.B. 1625). Before that decision the English cases had evolved from the theory that only ancient mills could prescribe for water to the doctrine that even a recently erected mill located on an ancient stream was entitled to an uninterrputed flow. See Lauer, The Common Law Background of the Riparian Doctrine, 28 Mo. L. Rev. 60, 83-85 (1963). Thus, even before Shury v. Piggot, the English courts had arrived at a "natural flow" doctrine that allowed any mill owner to bring an action for diversion, though it was still couched in the language of ancient use. While English law moved on to an explicit statement of a modern "natural right" doctrine, eighteenth century Massachusetts law remained fixed at the earliest stage in the English evolution.

In Shorey v. Gorrell (1783), cited in W. Cushing, supra note 10, the Massachusetts Supreme Court misconstrued English authority to hold that the only basis for preventing interference with the flow of water was a right gained by prescription. In rejecting the plaintiff's claim to a right derived from mere priority of appropriation, the court also observed that since his mill was in existence for only eighteen years it was not old enough for a prescriptive right to accrue. After this case, Massachusetts pleadings always sound in prescription when a contract is not involved, but a crucial change takes place that imitates the earlier English developments discussed above. By 1801, James Sullivan's statement of Massachusetts water law, supra note 11, at 272-73, included only the requirement that a mill be located on an ancient stream, which again amounted to no more than a disguised version of the natural right doctrine. See also Perham, American 
The new circumstance that encouraged this change was the advent of large dams. While the original action for diversion placed lower millowners at a relative advantage since there was no one below them to injure, the erection of large dams introduced the possibility of equivalent injury by forcing water back upstream and causing damage to upper mills. Thus, the theoretical potential of the natural flow rule to check all development was made actual. This change forced courts to confront one of the great, and essentially unsettled, issues in nineteenth century America: how much certainty and predictability the law would guarantee to those who invested in economic development. Should the first person to build a mill be assured that his water supply would not be diminished by a subsequent upstream occupant? Could a guarantee be given without conferring a monopoly on the first developer?

There were two basic responses to this problem. The first was to recognize a right to interfere with the flow of water based on priority of appropriation. This view, though often coupled with the natural flow doctrine, began to take on a life of its own in the first quarter of the century. ${ }^{41}$ The second response was a reasonable use or balancing

Precedents of Declarations 196, \#1, note (1802), which explicitly states the fictionalized result of this change: "In a declaration for turning a watercourse, it is good to state it as an ancient watercourse which has been accustomed to run to the PIf.'s mill, without setting forth any prescription; for these words are tantamount." And although there is some evidence around the turn of the century that courts were beginning to look skeptically at these prescriptive claims, see note 52 infra, the theory was not finally abandoned in Massachusetts until 1827. See Anthony v. Lapham, 22 Mass. (5 Pick.) 175 (1827). See also Weston v. Alden, 8 Mass. 136 (1811); Colburn v. Richards, 13 Mass. 420 (1816); Cook v. Hull, 20 Mass. (3 Pick.) 269 (1825).

The original Massachusetts decision consciously to limit the action for diversion to prescriptive claims was based on far-reaching economic considerations, analogous to those that later induced courts to modify the natural flow rule. In Shorey v. Gorrell, cited in W. Cushing, supra note 10, the Massachusetts court equated the right to prevent diversion with a right to recover for competitive injury, which it regarded as pernicious. "For it is too much opposed to the general good," Chief Justice Cushing declared, "to say that a man shall not erect a mill or institute a school merely because there are others in the neighbourhood." Indeed, the claim-and rejection-of a rule of prior appropriation in this early case illustrates again that it was only when the natural flow rule was rejected that there was any need for a separate theory of prior appropriation. By the turn of the century, however, these considerations seem to have been forgotten, and the continuing persistence of prescriptive claims apparently reflects only an attempt to satisfy the technical rule that title and not merely possession had to be alleged in order to bring an action for diversion. See Pearson v. Tenny (1802), 3 N. DaNE, supra note 11, at 14. See also 2 W. Blackstone Commentaries *195-99; Jones v. Waples, 2 Del. Cas. 159, 162-63 (1802); Twiss v. Baldwin, 9 Conn. 291, 301-02 (1832).

41 In 1821, the Massachusetts Supreme Court intimated adoption of a rule of priority, Fatch v. Dwight, 17 Mass. 289 (1821), to which Chancellor Kent, in a thoroughly confused statement of water law, offered the prestigious approbation of his Commentaries. "If the right of prior occupancy ... did not go thus far," Kent wrote, acknowledging the basic 
test. Chancellor Kent, who managed not only to defend the natural flow doctrine but to approve a rule of priority as well, was also sympathetic to some form of reasonable use test. The natural flow doctrine, he wrote, following Story, "must not be construed literally, for that would be to deny all valuable use of the water to the riparian proprietors" since "rivers and streams of water would become utterly useless, either for manufacturing or agricultural purposes." 42

While either a priority or a reasonable use test would have extricated the courts from the antidevelopmental consequences of the common law, these two doctrines were not interchangeable. A rule of priority had monopolistic consequences: a reasonableness doctrine based on a notion of proportional use resulted in competitive development. A contest between the two was inevitable. When the doctrinal confusion began to clear up in the second quarter of the nineteenth century, virtually all courts rejected prior appropriation, because, in the prescient language of the New York Supreme Court, it meant that "the public, whose advantage is always to be regarded, would be deprived of the benefit which always attends competition and rivalry."43

\section{B. Prescription: "a fatal enemy to modern improvements"}

Having rejected prior appropriation, American courts turned their attack on the monopolistic and exclusionary predilections of property law to the doctrine of prescription. The conception that prescriptive rights to certain kinds of intangible property may be acquired only after adverse use for a specified period of years did not clearly emerge in American law until the nineteenth century. ${ }^{44}$ Before that time, a wide variety of property interests could be acquired by long, but not adverse, usage. For example, the operation of a market or collection of tolls for a ferry, ${ }^{45}$ though invalid at the outset without a grant from the king, could eventually ripen into a right to exclude all competition. ${ }^{46}$ The owner of a house could, after a period of years, claim a prescriptive easement for "ancient lights" and prevent his neighbor from erecting

dilemma of proponents of the old law, "the water privilege would seem to be rendered wholly useless for mill purposes to all parties." 3 Commenraries 358 n.(b) (1st ed. 1828).

423 Commentaries 355 n.(b) (1st ed. 1828).

43 Palmer v. Mulligan, 3 Gai. R. 307, 314 (N.Y. Sup. Gt. 1805).

44 See 7 W. HoldswORTH, A HISTORY OF ENGLISH LAW 343-50 (1926); Acquisition of Title by Prescription, 19 AM. JURIsT 96, 98-101 (1838).

453 W. Blackstone, Commentartes *218-19; Mosley v. Chadwick, 7 Barn. \& Cres. 47 n. (a) (K.B. 1782); Chadwick v. Proprietors of Haverhill Bridge (1787) in 2 N. DANE, ABRIDGEMENT 686-87 (1823); Tripp v. Frank, 4 T.R. 668 (1792).

46 Indeed, even after the attack on royal monopolies in England, custom legitimized long-standing monopolies that would otherwise have been illegal. $10 \mathrm{~W}$. HoLDsworth, supra note 44 , at 402 . 
any buildings on adjoining property that would interfere with his own enjoyment of sunlight. ${ }^{47}$ Riparian owners could acquire the right to exclude all others from injurious use of water merely by having appropriated use of the water many years before. ${ }^{48}$ Finally, prescription legitimized a variety of restraints on trade, so that well into the eighteenth century English courts allowed damage actions against consumers who departed long-standing business relationships to take their trade elsewhere. ${ }^{49}$ Even in the nineteenth century, English courts entertained damage actions for competitive injury to markets by prescription. ${ }^{50}$

The doctrine of prescription confronted courts in a developing society with the anomaly of giving preference to old over new property merely because it was old. More fundamentally perhaps, the law of prescription had come to be associated with the monopolistic and restrictive practices of a feudal society. Thus, in his thoughful and informative edition of Blackstone's Commentaries, St. George Tucker of Virginia insisted that the English recognition of titles by prescription had not been imported into the common law of Virginia, primarily because Virginia had been settled too recently for prescriptive rights to accrue. ${ }^{51}$ There is no question, moreover, that Tucker was aware of the economic and social implications of prescription.

473 W. Blackstone, Commentaries *217. See also J. Sullivan, supra note 11, 268; Story v. Odin, 12 Mass. 157 (1815).

48 See Ingraham v. Hutchinson, 2 Conn. 584 (1818); Sherwood v. Burr, 4 Day 244 (Conn. 1810). For the doctrine of prescription in Massachusetts water cases, see note 40 supra.

49 See Cort v. Birkbeck, 1 Doug. 218 (K.B. 1779); White v. Porter, Hard. 177, 145 Eng. Rep. 439 (Exch. 1672); 3 W. Blackstone, Commentaries * 235.

50 Mosley v. Walker, 7 Barn. \& Cres. 40 (K.B. 1827). In a related sphere, the doctrine of prescription operated in the American colonies so as to transform long established private associations into municipal corporations, thereby conferring upon them the ancient privileges of suing, levying taxes, and making by-laws that were legally binding on all of their members. After 1780, Massachusetts no longer recognized corporations by prescription. O. HandiIn \& M. HANDLIN, CoMmonWealth: MAsSachusetTs 1774-1861, at 162. (1947); cf. 1 N. DANE, ABRidgement, 459 (1823). Similarly, in Virginia after the Revolution all corporations were created by legislative act. 1 W. BLAckstone, Commentaries 472 n.2 (St. G. Tucker ed. 1803). Nevertheless, long use was admitted as evidence of a presumably destroyed corporate charter, Dillingham v. Snow, 5 Mass. 547, 551-52 (1809), and some states even went further to allow proof of long use when there was no reason to suppose that an original charter ever existed. See Greene v. Dennis, 6 Conn. 292, 302-04 (1826).

51 See 2 W. BLackstone, Commentaries 31 n.2, 36 n.7, 266 n.l (St. G. Tucker ed. 1803). Similarly, Zephaniah Swift of Connecticut, who must have been familiar with the multitude of prescriptive actions in neighboring Massachusetts, nevertheless remarked in 1796 that "this country has been so lately settled, that the right of prescription, has hardly had time to operate." $1 \mathrm{Z}$. SWIFT, A System of THE LAwS of the State of CoNNECTTCUT 442 (1795). Later, as Chief Justice of Connecticut, Swift recognized prescription with a vengeance in Ingraham v. Hutchinson, 2 Conn. 584 (1818). In Cortelyou v. Van Brundt, 2 Johns. 357, 361 (N.Y. Sup. Ct. 1807), counsel for the prevailing side argued that 
Although there is evidence that courts were becoming resistant to prescriptive claims around the turn of the century, ${ }^{52}$ it was only in the case of Ingraham $v$. Hutchinson ${ }^{53}$ that the doctrine came directly under attack. While the court upheld a downstream riparian landowner's prescriptive claim to obstruct the flow of water, it faced a powerful and influential dissent by one of the most distinguished judges of the period. Judge James Gould maintained for the first time that without adverse use the lower proprietor could not claim an exclusive right to water regardless of how long before he had appropriated the flow. "The use, which the plaintiff has made of the stream has been neither a legal injury, nor an inconvenience of any kind, to the defendant. It was nothing, of which the defendant had any right to complain. $\mathrm{He}$

"Prescriptive rights are not to be favoured; in England they are considered as rights, the origin of which cannot be traced; but in this country almost every right can be traced to its origin." But see 1 N. DANE, supra note 50, at 459, which asserts that "though the country is young, yet it is old enough for prescription." Nevertheless, Dane himself was greatly skeptical of the entire doctrine of prescription and called forth a major legal controversy over its legitimacy. See text at note 58 infra.

52 In Palmer v. Mulligan, 3 Gai. R. 308 (N.Y. Sup. Ct. 1805), the court ignored the plaintiff's prescriptive claim to water, treating it as if it were no more than a claim of prior appropriation. See id. at 315d (Thompson, J., dissenting). By the end of the eighteenth century, Massachusetts courts seem to have treated allegations of prescription as nontraversable, Perham, supra note 40 , perhaps producing a reaction. Writing in 1801, Sullivan cited a 1798 water rights decision based on prescription "which called for more investigation than had been usual in cases of this kind," J. Sullivan, supra note 11, at 273, an indication that the Massachusetts courts were beginning to examine prescriptive claims substantively. Indeed, in 1803, the Massachusetts court stated that even sixty years use was not sufficient to establish title by prescription. Devereux v. Elkins, 5 N. DANE, ABRIDGEMENT 568 (1824).

In Connecticut, two water cases in 1783 and 1793 also rejected prescriptive claim of a downstream landowner to an undiminished flow of water. Perkins v. Dow, 1 Root 535 (1793), citing Howard v. Mason (unreported 1783). In two other important early nineteenth century cases, the Pennsylvania and Connecticut supreme courts rejected prescriptive claims to exclusive fishing rights, Carson v. Blazer, 2 Binn. 475 ( $\mathrm{Pa} .1810)$, and to an exclusive stagecoach franchise, Nichols v. Gates, 1 Conn. 318 (1815). In a much narrower opinion, the New York Supreme Court sidestepped the question of whether the right to fish could be acquired by prescription, holding that even if it could, prescription could not justify building fishing huts on another's land. Cortelyou v. Van Brundt, 2 Johns. 357 (1807).

By this time, however, the English courts had already changed the theory of prescription, having begun in 1761 to analogize the prescriptive period to that required for the statute of limitations to run. J. ANGerL, AN INQUiRY INTo tHe RULE of LAw which CREATES

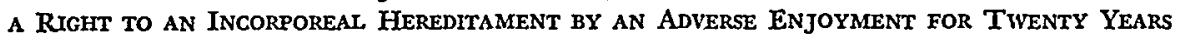
23-31 (1827); 7 W. Holdsworth, supra note 44, at 343-50. Thus, by 1815, the attack on prescription had abated as the American courts followed the English judges in reducing the prescriptive period, first to sixty years, Thurston v. Hancock, 12 Mass. 220, 225 (1815), and eventually to twenty years, Bolivar Mfg. Co. v. Neponset Mfg. Co., 33 Mass (16 Pick.) 241 (1834), and in one state to fifteen years. Ingraham v. Hutchinson, 2 Conn. 584 (1818).

532 Conn. 584 (1818). 
has, therefore, acquiesced in no usurpation of his rights; and has been guilty of no neglect, in not asserting them sooner." 54 The effect of the majority's opinion, Gould pointed out, was that the upstream defendant permanently forfeited any right to build because he did not erect his mill within the prescriptive period "whether it would, have been of any use to him, or not-and whether he was in a condition to build it, or not."55

As Gould saw, without his conception of adverse use, the doctrine of prescription was nothing more than a modified version of the rule of prior appropriation, with the same monopolistic and exclusionary results. With Gould's requirement of implied consent by one party to an invasion of his property rights, there was no way in which a later mill orvner could ever claim more than his proportionate share of water without usurping the rightful share of an already existing mill.

In one sense, Gould was simply redefining the conditions necessary for finding adversity. Under the traditional view, a mill owner fortunate enough to be left alone on a stream for the prescriptive period would have been regarded as exercising a claim adverse to the potential rights of his riparian neighbors to build mills in the future. Gould, however, would only have recognized a user adverse to existing mills. Under Gould's definition of adversity, prescription could never justify monopoly. His view was widely adopted ${ }^{56}$ once the rule of prior appropriation had been overwhelmingly rejected in the second quarter of the nineteenth century. Legal doctrine was thus fundamentally transformed to prevent the first occupant on a stream from excluding all other mill owners, regardless of how long before he had established his works.

54 Id. at 595 .

$55 I d$.

¿50 Stokes v. Upper Appomatox Co., 30 Va. 343, 360, 3 Leigh 318, 334 (1831); Hoy v. Sterrett, 2 Watts 327, 330-31 (Pa. 1834); Thurber v. Martin, 68 Mass. (2 Gray) 394 (1854); Pratt v. Lamson, 84 Mass. (2 Allen) 275, 287-89 (1861); see Norton v. Volentine, 14 Vt. 289, 245-46 (1842), applying the same doctrine to upstream users; cf. Holsman v. Boiling Spring Bleaching Co., 14 N.J. Eq. 335, $344-46$ (1862). See also Acquisition of Title by Prescription, 19 AM. JURrsr 96 (1838). Modern water law confirms this trend. "[P]rescriptive rights cannot be acquired against potential upstream users and can be acquired against downstream users only where their 'reasonable' use has been interfered with for the full statutory period." Haber, Introductory Essay to ThE LAW of WATER Allocatron, at xxix (D. Haber \& S. Bergen eds. 1958). On the other hand, the intimately related issue of whether a nonmill owner could bring a cause of action in order to prevent the prescriptive period from running, e.g., Whipple v. Cumberland Mfg. Co., 29 F. Cas. 934, 935-36 (No. 17,516) (C.C.D. Me. 1843), did not undergo any comparable change in spite of Chief Justice Shaw's efforts in that direction. Compare Elliot v. Fitchburg R.R., 64 Mass. (10 Cush.) 191, 196-97 (1852), with Lund v. New Bedford, 121 Mass. 286 (1876), and Parker v. Griswold, 17 Conn. 288, 301-08 (1845). See also Haar \& Gordon, Legislative Change of Water Law in Massachusetts, in The LAW of Water Allocation, supra at $23, \mathrm{n} .98$. 
A still greater shock to the old law of prescription was the publication of Dane's Abridgment in 1824. Although Dane first acknowledged that the recent settlement of the country alone was no bar to prescription, ${ }^{67}$ he went on to mortify the defenders of tradition by declaring that prescription was a mere "modern doctrine" that "cannot yet be considered as established law." 58 In a long and technical reply to both Dane and Judge Gould, Joseph Angell piled on old legal authorities to demonstrate that the rule of prescription could be "explained and defined with very great precision." 59 But Angell had entirely missed the point. The main issue could not be resolved by appealing to the authority of an established legal tradition from which the new doctrine represented a conscious departure. By defining the issue in terms of what had traditionally constituted property rights, Angel fell out of touch with a movement to limit sharply the power of property owners to determine the scope of economic development.

In one ironic sense, Angell displayed a degree of prescience. Angell, who could not allow himself to think that his differences with Gould could be due to anything but a misunderstanding of recognized authority, argued with a confident flourish that "[i]n principle, there is no difference whatever" between the prescription for water and for sunlight, and that Gould's position, as applied to the latter, "conflicts with what has uniformly been regarded as established law, for many centuries." enabled the owner of an ancient tenement to prevent his neighbor from undertaking any building that would interfere with his own enjoyment of sunlight, rested on even more long-standing legal authority than did the doctrine of prescription in water cases. And, as in the water cases, the rule protecting ancient lights could run against a property owner who had never acted. Judge Gould, however, had recognized this very analogy and declared the doctrine of ancient lights "anomalous" in the law.

Both Angell and Gould were correct in this: under Gould's approach there could be no stopping short of transforming the whole law of prescription. And in the leading case of Parker $v$. Foote, ${ }^{61}$ the New York court, following Gould's analysis, overthrew the doctrine of

57 I N. DANE, supra note 11 , at 459.

$683 \mathrm{id}$. at $54-55$. It is unclear from the passage whether Dane is attacking prescription in principle or only various applications of the doctrine. Nevertheless, he was understood as challenging the doctrine itself.

$59 \mathrm{~J}$. ANGELL, supra note 52, at 63.

60 Id. at 102-03.

6119 Wend. 309 (N.Y. Sup. Ct. 1838). 
ancient lights. ${ }^{62}$ It "cannot be applied in the growing cities and villages of this country," the court declared, "without working the most mischievous consequences." 33 By the Civil War, this attitude had acquired such momentum that it challenged even the well-established doctrine that a right to support of buildings could be acquired by prescription. ${ }^{64}$

The most striking rejection of the common law assumption that long use was sufficient to create an exclusive property interest occurred in the great Charles River Bridge case. ${ }^{.5}$ The bridge proprietors, claiming an exclusive franchise as successors in interest to an ancient ferry, sued a recently chartered bridge company for damages due to competitive injury. In rejecting their prescriptive claim, Justice Morton of the Massachusetts court turned to his own purposes the common law fiction that long use was evidence of an original lost grant by noting that, since there was evidence of an actual grant, "the plaintiffs cannot now call to their aid any principles or reasoning peculiar to this kind of title, or any rules of evidence applicable to this mode of proof."'66 Although Justice Story had only recently attempted to commit American law to the position that use for twenty-one years created a conclusive presumption of title, ${ }^{67}$ Morton and others hostile to prescriptive claims treated

62 The decision had the effect of overthrowing, as one contemporary put it, "a fatal enemy to modern improvements in building ...." Noyes, The Legal Rules Governing Enjoyment of Light, 23 AM. JURISr 52, 57-58 (1840).

6319 Wend. at 318 . In his Commentaries, Chancellor Kent had entirely misunderstood the question. Having incorrectly assumed that the right to light could be based on mere priority and not prescription, he proposed that one could lose the right by nonuse for a prescriptive period. " $[\mathrm{I}] \mathrm{t}$ is a wholesome and wise qualification of the rule," he concluded, "considering the extensive and rapid improvements that are every where making upon real property." $3 \mathrm{~J}$. KeNT, Commentaries 450 (2d ed. 1832). Because he started from an erroneous major premise, the "qualification" he proposed was entirely consistent with traditional legal conceptions.

64 See The Natural Right of Support from Neighbouring Soil, 1 Am. L. REv. 1, 9-11 (1866). The first case to reject the doctrine was Mitchell v. Rome, $49 \mathrm{Ga} .19$ (1873).

o5 Charles River Bridge v. Warren Bridge, 24 Mass. (7 Pick.) 344 (1830), aff'd, 36 U.S. (11 Pet.) 420 (1837).

6024 Mass. (7 Pick.) at 449-50. The prevailing technical objection to prescription at the turn of the century was that the country was too young for prescription to operate. See note 51 and text at note 58 supra. As Morton's opinion demonstrates, by the 1830 s the technical challenge had shifted to an exposure of the fictional character of the "lost grant" theory of prescription, see, e.g., Parker v. Foote, 19 Wend. 309 (N.Y. Sup. Ct. 1838); Spear v. Bicknell, 5 Mass. 125, 130 n.(a) (Rand. ed. 1835); 3 N. DANE, supra note 11, at 54-55, which had been only recently developed by the English courts. See 7 W. Holdsworth, supra note 44 , at $347-49$.

67 Tyler v. Wilkinson, 24 Fed. Cas. 472, 474 (No. 14,312) (G.C.D.R.I. 1827). The entire question of whether prescription created a conclusive presumption of right was in a state of total confusion in this period. This confusion, of course, reflected the courts' uneasiness with the doctrine of prescription itself. For Angell's attempt to create a coherent rule, see J. ANGELL, supra note 52, at 36-68. 
long use as no more than rebuttable evidence of title ${ }^{68}$ and were thus able to circumvent a long line of English cases recognizing exclusive franchises based only on prescription.

Justice Baldwin undertook an elaborate justification of the Supreme Court's affirmance of the Charles River Bridge case, emphasizing that none of the English decisions concerning prescriptive markets and ferries could be adopted in America since "they grow out of feudal tenures, are founded on feudal rights, and are wholly unknown in this country . . . "69 Even Justice McLean, whose views on the merits of the case favored the first bridge company, believed that the recent settlement of the country and "its rapid growth in population and advance in improvements" prevented most property from being acquired by long usage. "Such evidence of right," he concluded, "is found in countries where society has become more fixed, and improvements are in a great degree stationary."'70

At its deepest level, the attack on prescription represented another effort to free American law from the restraints on economic development that had been molded by the common law's feudal conception of property. By the second quarter of the nineteenth century the common law doctrine of prescription had been considerably narrowed to prevent exclusive rights from accruing merely on the basis of long use, and American law had moved into what Francis Hilliard, writing in a different context, called an "anti-prescriptive age."71

\section{The Mill Agts: Property as an Instrumental Value}

The various acts to encourage the construction of mills offer some of the earliest illustrations of American willingness to sacrifice the sanctity of private property in the interest of promoting economic development. The first such statute, enacted by the Massachusetts colonial legislature in 1713, envisioned a procedure for compensating landowners when a "small quantity" of their property was flooded by the raising of waters for mill dams. ${ }^{72}$ The statutory procedure was rarely used, however, since the Massachusetts courts refused to construe the act to eliminate the traditional common law remedies for trespass

68 The same doctrine is advanced in Parker v. Foote, 19 Wend. 309 (N.Y. Sup. Ct. 1838).

69 H. Baldwin, A General View of the Origin and Nature of the Constitution of THE UNTrED STATES 157 (1837). Baldwin intended this work to be included as an appendix to volume 11 of Peters Reports, but it was not prepared in time for publication there. It does appear in 9 L. Ed. 868, 949 (837).

7036 U.S. (11 Pet.) at 562-63.

71 F. Hilliard, Elements of Law viii (1835).

72 Province Laws 1713, ch. 15. 
or nuisance. ${ }^{73}$ After the act was amended in 1795 and 1798 , mill owners began to argue that it provided an exclusive remedy for the flooding of lands. ${ }^{74}$ As a result, the mill acts adopted in a large number of states and territories ${ }^{75}$ on the model of the Massachusetts law were, more than any other legal measure, instrumental in dethroning landed property from the supreme position it had occupied in the eighteenth century world view, and ultimately, in transforming real estate into just another cash-valued commodity. ${ }^{76}$ The history of the acts are a major source of information on the relationship of law to economic change. For reasons of convenience the discussion that follows concentrates on the Massachusetts experience, which, though particularly rich, is not atypical.

Under the 1795 Massachusetts statute, ${ }^{77}$ an owner of a mill situated on any nonnavigable stream was permitted to raise a dam and flood the land of his neighbor, so long as he compensated him according to the procedures established by the act. The injured party was limited to yearly damages, instead of a lump sum payment, even if the land was permanently flooded, and the initial estimate of annual damages continued from year to year unless one of the parties came into court and showed that circumstances had changed. The act conferred extensive discretion on the jury, which, in addition to determining damages, could prescribe the height to which a dam could be raised as well as the time of year that lands could be flooded. Unlike the statutes in

73 Dench v. Jones (1783), in W. Cushing, supra note 10; T. Parsons, Precedents 51-52 (1775) (Ms. Treasure Room, Harvard Law School). Published common law actions for flooding betwcen 1768 and 1778 do not mention the mill act. Keen v. Turner (1768), in 1 Legal Papers of John Adams 242 (L. Wroth \& H. Zobèl eds. 1965); Wilkins v. Fuller (1770), in $i d$. at 274 .

$74 \mathrm{~J}$. Sullivan, supra note 11 , at $277-78$. The frequency of mill act cases after 1798 reflects the growing conviction that the statutory remedy was finally intended to preclude any common law action. Buckman v. Tufts (1800), in J. Sullivan, supra note 11, at 278-82; 3 N. DANe, supra note 11, at 16; Batchelder v. Peabody (1800), in J. Srory, A Selection of Pleadings in Civit. Actions 457-58 (Ist ed. 1805); Lowell v. Spring, 6 Mass. 398 (1810). As late as 1813, the Supreme Judicial Court still reserved decision on the question whether the statutory remedy was exclusive, Staple v. Spring, 10 Mass. 73, 74-75 (1813), and so held only in 1814. Stowell v. Flagg, 11 Mass. 364, 365 (1814). In his note to Johnson v. Kitteredge, 17 Mass. 76, 79 n.5, (B. Rand ed. 1832), Benjamin Rand nevertheless argued that the statute "should have been regarded as only giving an additional remedy," which, of course, would have made it nearly worthless.

75 A complete list of all such legislation to 1884 appears in Head v. Amoskeag Mfg. Co., 113 U.S. 9, 17 n.* (1884).

78 In England, by contrast, the construction of mills was encouraged by the typically feudal device of allowing the proprietor to recover damages against a customer who took his trade elsewhere. 3 W. BLACrstone, Commentaries *235; J. ANGeld, supra note 31 at 119 n.19.

77 Act of Feb. 27, 1795, ch. 74, [1794-96] Mass. Acts \& Resolves 443. 
some states, such as Virginia, ${ }^{78}$ the Massachusetts law authorized the mill owner to flood neighboring lands without seeking prior court permission. ${ }^{79}$ Thus, except for the power of the jury to regulate their future actions, there was no procedure for determining in advance the utility of allowing mill owners to overflow particular lands.

The exclusive remedial procedures of the mill acts foreclosed four important alternative avenues to relief. First, they cut off the traditional action for trespass to land, ${ }^{80}$ in which a plaintiff was not required to prove actual injury in order to recover. In a mill act proceeding a defendant could escape all liability by showing that, on balance, flooding actually benefitted the plaintiff. ${ }^{81}$ Second, the statutory damage formula removed the possibility of imposing punitive damages in trespass or nuisance. The common law view had been that unless punitive damages could be imposed, it might pay the wrongdoer to "keep it up forever; and thus one individual will be enabled to take from another his property against his consent, and detain it from him as long as he pleases." 82 A third form of relief at common law allowed an affected landowner to resort to self-help to abate a nuisance. ${ }^{83} \mathrm{In}$ deed, there are a number of reported cases in which mill dams not covered by the protection of the mill acts were torn down by neighbors claiming to enforce their common law rights. ${ }^{84}$ Finally, the acts foreclosed the possibility of permanently enjoining a mill owner for having created a nuisance. ${ }^{85}$

78 See Wroe v. Harris, 2 Va. (2 Wash.) 126 (1795).

79 Kentucky and, before 1798, Rhode Island also required prior authority. In 1798 Rhode Island modeled its statute after that of Massachusetts. The Law of Water Privileges, 2 Am. Jurist 25, 31-32 (1829). See also P. Coleman, The Transformation of Rhode IsLAND 1790-1860, at 76-77 (1963).

80 For an example of a common law trespass action for flooding, see Wright v. Cooper, I Tyler 425 (Vt. 1802). Cf. Merritt v. Parker, I N.J.L. 460 (I795). See also King v. Tarlton, 2 Har. \& McH. 473 (Md. 1790).

81 See text and notes at notes 94-96 infra.

82 See Bradley v. Amis, 3 N.C. 399,400 (1806) (note by reporter): "Sometimes the profits of ... merchant mills ... are of much greater value in one year, than the fee simple of the annoyed property. ... [T] equivalent to the profits gained by the erection, or by damages to such an amount as will render those profits not worth pursuing." See v Deberry, 2 N.C. 248 (1795). The identical view prevailed as to trespasses. In trespass, "[ $t]$ he value of the property, or the amount of the injury done to it, is not the only ground of damages . . . . Were it otherwise, a person so disposed might forcibly dispossess another of any articles of property at his pleasure, and compel the owner, however, unwilling, to accept of the value in its stead." Edwards v. Beach, 3 Day 447, 450 (Conn. 1809).

83 Merritt v. Parker, 1 N.J.X. 460, 465 (1795).

84 Gleason v. Gary, 4 Conn. 418 (1822); Dimmett v. Eskridge, 20 Va. (6 Munf.) 308 (Va. 1819); Hodges v. Raymond, 9 Mass. 316 (1812).

85 Not all states had courts of equity. There was no explicit grant of equity jurisdiction to restrain a nuisance in Massachusetts, for example, until 1827, although many contended 
In the early nineteenth century the need to provide a doctrinal rationale for the extraordinary power that the mill acts delegated to a ferw individuals was acute. Not only had the use of water power vastly expanded in the century since the original Massachusetts act, but there was also a major difference between the eighteenth century grist mill, which was understood to be open to the public, and the more recently established saw, paper, and cotton mills, many of which served only the proprietor. In Stowell $v$. Flagg, ${ }^{86}$ Chief Justice Parker said "[t] he statute was made for the relief of mill owners from a multiplicity of suits," because the legislature found that the common law remedy would "so burthen the owner of a mill with continual lawsuits and expenses" when he overflowed his neighbor's land.87 Parker was not troubled by the statutory mode of compensation through annual payment of damages, which, in effect, compelled the landowner to make a loan to the mill owner and thereby enabled the mill owner to amortize any permanent damage he caused. Nor did he point out that under the common law there was no private right to flood adjoining land, even upon making just compensation.

By viewing the statute as entirely remedial, Parker did not have to portray the enterprise as sufficiently public in nature to bring it within the power of eminent domain. Troubled by the enormous potential for unplanned economic change that the mills acts made possible, however, Parker did suggest that the 1798 statute was "incautiously copied from the ancient colonial and provincial acts, which were passed when the use of mills, from the scarcity of them, bore a much greater value, compared to the land used for the purpose of agriculture, then at present." 88

Parker's language seems to imply that the only public purpose required in order to justify an extensive invasion of private rights was an increase in total utility-and that such a calculation was within the exclusive domain of the legislature. If the legitimacy of a taking was a function only of the relative values of the adjoining properties, any compelled transfer would be lawful so long as compensation was required. It is more likely, however, that Parker was merely questioning the prudence of the legislative judgment, while never doubting that mills were public in terms of whom they served.

that a general statute of 1817 conferred such authority. See Charles River Bridge v. Warren Bridge, 23 Mass. (6 Pick.) 376, 383, 394 (1828); Woodruff, Chancery in Massachusetts, 9 B.U.L. REv. 168 (1929).

8611 Mass. 364 (1814).

87 Id. at 366.

88 Id. at 368 . 
By 1814, the significance of the growing separation between public and private enterprise was only beginning to penetrate the judicial mind. Some still conceived of mills as a form of public enterprise in which competition was impermissible. ${ }^{89}$ Business corporations were only beginning to upset the old corporate model, in which the raison d'etre of chartered associations was their service to the public. Nor is there any evidence that the increasingly private nature of mills, which was painfully evident to everyone fifteen years later, had as yet caused judges the slightest conceptual difficulty. At this time in Virginia, for example, where the old corporate model still prevailed, judges were also clear that the state's mill act could be defended on the ground that "the property of another is, as it were, seized on, or subjected to injury, to a certain extent, it being considered in fact for the public use ...."90

The dramatic growth of cotton mills after 1815 provided the greatest incentive for mill owners to flood adjoining land ${ }^{91}$ and, in turn, brought to a head a heated controversy over the nature of property rights. The original mill dams were relatively small operations that caused some upstream flooding when proprietors held back water in order to generate power. With the growth of large integrated cotton mills, however, the flooding of more lands became necessary not only because larger dams held back greater quantities of water but also because of the need to generate power by releasing an enormous flow of water downstream. In light of this fact, the Massachusetts legislature amended the mill act in 1825 to allow the flooding of "lands . . . situated either above or below any mill dam ... ."92 Two years later, in the Wolcott Woollen case, ${ }^{93}$ the Supreme Judicial Court of Massachusetts, adopting its customary posture of resignation, observed only that " $[t]$ he encouragement of mills has always been a favorite object with the legislature, and though the reasons for it may have ceased, the favor of the legislature continues." It thereby extended the protection of the mill act to what were essentially manufacturing establishments, even though regulating the flow and assessing yearly damages were far more difficult than in the case of upstream flooding, where the extent of damage could easily be predicted once the allowable height of the dam was determined.

89 In his Litchfield Law School lectures, Judge Tapping Reeve questioned whether "other people have a right to build so near [an existing millowner] as to lessen his profits." Henry H. Fuller's Notes of Lectures on Tapping Reeve and James Gould at the Litchfield Law School, vol. UI, at 467-68 (1812-13) (Ms. Treasure Room, Harvard Law School).

90 Skipwith v. Young, 19 Va. (5 Munf.) 276, 278 (1816).

$91 \mathrm{~J}$. ANGELL, supra note 19 , at 62 .

92 Act of Feb. 26, 1825, ch. 153, \& 1 [1822-25] Mass. Laws 658.

93 Wolcott Woollen Mfg. Co. v. Upham, 22 Mass. (5 Pick.) 292, 294 (1827). 
Even more significant, the mill owners succeeded in inducing the court to extend the act to cover a situation that the legislature could scarcely have envisioned. Thus, a mill that had purchased land and built a new dam more than three miles upstream from its existing mill, was allowed to overflow all the land between the dam and the original mill site. In effect, the court gave mill owners virtually unlimited discretion to destroy the value of lands far in excess of any benefit they might possibly receive.

Also in $1827,3^{94}$ the court applied another new section of the act ${ }^{95}$ to allow a defendant to escape damages entirely by showing that the irrigation benefits the plaintiff received from having his lands overflowed more than outweighed any injury he had incurred..$^{96}$ Representing the culmination of a quarter century's experience under the mill acts, this marked the final break with the eighteenth century conception of property, which regarded the flooding of land as a fundamental invasion of right regardless of actual damage. As one court at the end of the eighteenth century observed, "it is altogether immaterial whether [flooding] may be productive of benefit or injury. No one has a right to compel another to have his property improved in a particular manner; it is as illegal to force him to receive a benefit as to submit to an injury." 97 Under the mill act, however, mere interference with another's quiet enjoyment of land no longer possessed any independent claim to compensation. The only measure of damage was the effect on the productive value of land.

Manufacturing companies did not always regard coverage under the mill act as an unmixed blessing. In fact, after Wolcott Woollen they often sought to extract from the legislature better treatment than they could expect to win from a jury impanelled under the act. In Cogswell v. Essex Mill Corp..${ }^{98}$ for example, there occurred a reversal of the usual roles, with the plaintiff arguing for his remedy under the statute and the manufacturing company insisting on an action at common law. In its charter, the company had been guaranteed the right to raise its dam to a specified height and to flood the adjoining lands at all times of

94 Avery v. Van Deusen, 22 Mass. (5 Pick.) 182 (1827).

95 Act of Feb. 26, 1825, ch. 153, § 3 [1822-25] Mass. Laws 658.

96 Even without a specific statutory provision, however, the Supreme Judicial Court had long assumed that a defendant did not have to pay for flooding in the absence of damages, Lowell v. Spring, 6 Mass. 398 (1810). Indeed, in a 1769 common law action for flooding the court apparently had allowed the defendant to show that his action had improved the plaintiff's land. Keen v. Turner, in 1 Legar PAPERs of JoHN ADAMs, supra note 73, at 242, $244-45$.

97 Merritt v. Parker, 1 N.J.L. 460,466 (1795).

9823 Mass. (6 Pick.) 94 (1828). 
the year. The company "would not have accepted a charter containing the mill act," it argued, for that "would subject them to the fluctuating estimates of juries" 99 to determine both the time and extent of their activity. Instead, the company preferred to make a lump sum payment of damages in a common law action in return for a guarantee of certainty in all other respects. The court held for the company on the theory that the charter provision took precedence over the mill act. Yet even in this case it is striking how far the ideology of the mill acts had influenced thinking about the rights of property. Courts had ceased questioning the right of a mill owner with legislative authorization to impair the value of adjoining land for an essentially private purpose, so long as compensation was provided. The supervisory role of the jury, which initially imparted an important measure of legitimacy to this novel undertaking, could finally be dispensed with entirely.

Extension of the mill act to manufacturing establishments brought forth a storm of bitter opposition. One theme-that manufacturing establishments were private institutions-appeared over and over again. One commentator, for example, pointed out that the original mill act had been enacted at the time when "the country had been in a state of slow progress from a wilderness to cultivation" and "[l]ands were of comparatively little value, while the support of corn and saw mills ... was . . of vital necessity ... ." Under these circumstances, he said, mills could reasonably have been regarded as "public easements." With the extension of the acts to manufacturing establishments, however, the essential question was changed to "the right to apply the property of any one against his consent to private uses . . ."100 The distinguished Boston lawyer, Benjamin Rand, disputed the assertion in Stowell $v$. Flagg that the mill act merely substituted one remedy for another. "Such an invasion of private property," he declared, "can only be defended in a case of great public necessity and utility." 101 Finally, those whose lands were flooded complained bitterly that "there is no remedy worth pursuing," so that "but few of those who suffer seek any relief." "Generally," they observed, "the mills and mill seats are in the hands of the active and wealthy-able to make the sufferers repent, if they resort to the law." 102

The nearly unanimous denunciation of the mill acts soon brought

$99 I d$. at 96.

100 The Law of Water Privileges, 2 AM. JURIsr 25, 30-31, 34 (1829) (emphasis in original). 101 Stowell v. Flagg, 11 Mass 364, 366 n.a (Rand ed. 1832).

102 Maine Gitizens Memorial To the Legislature (c. 1833), broadside J 38, (Ms. Treasure Room, Harvard Law School). Maine, which separated from Massachusetts in 1820, continued to enforce the Massachusetts mill act. For another attack on the act, see The Requisites to Dower and Who are Capable of It, 20 AM. JuRIsr 47, 60-63 (1838). 
forth a degree of change. From 1830, when Lemuel Shaw began his thirty year tenure as chief justice, the Massachusetts court began a marked retreat away from its earlier reluctant, but expansive, interpretation of the act. And after 1830, when the legislature eliminated the most notorious windfall to mill owners by extending to the injured party the opportunity to recover permanent damages, ${ }^{103}$ the leading attraction of proceeding under the act was eliminated. ${ }^{104}$

With this evidence of diminished legislative support, the Massachusetts court consistently rejected attempts to extend the statute to novel areas. Shaw's first mill act case ${ }^{105}$ posed the question whether the protection of the act extended to mills erected on artificial canals built for the purpose of drawing water away from natural streams. This issue presented the court with the opportunity to encourage a vast geographical expansion of industry under the protective wing of the mill act by sanctioning the flooding that would result from a network of canals on which dams would be built. If the mill act applied, "the owner of a parcel of low land may erect a mill upon it and bring water to the mill from any distant pond or reservoir, through the intermediate lands, without the permission of the owners of lands, and may rely for protection upon these statutes." 108 Although the court had seemed to sanction such a procedure only five years earlier, Shaw held that the benefits of the mill act extended only to riparian proprietors. The full import of the earlier decision was just becoming apparent as the dispute expanded beyond the fairly narrow and historically separate question of the proper means of regulating riparian owners to include the more general and necessarily controversial problem of determining the rights of landowners to use their lands.

Conceding that the mill acts "are somewhat at variance with that absolute right of dominion and enjoyment which every proprietor is supposed by law to have in his own soil,"107 Shaw nevertheless proceeded to offer a dual justification for the acts. The legislation could be defended, he wrote, "partly upon the interest which the community at large has, in the use and employment of mills"-a theory of eminent domain-"and partly upon the nature of the property, which is often

103 Act of March 22, 1830, ch. 122, § 2 [1828-31] Mass. Laws 474.

104 At the same time, however, the legislature began to play a more active role in the process of industrialization by specifically including in the charters of manufacturing corporations powers of flooding even more extravagant than the mill act would support. See, e.g., Boston \& Roxbury Mill Dam Corp. v. Newman, 29 Mass. (12 Pick.) 467 (1832). 105 Fiske v. Framingham Mfg. Co., 29 Mass. (12 Pick.) 68 (1832). But cf. Chase v. Sutton Mfg. Co., 58 Mass. (4 Cush.) 152 (1849).

$106 I d$. at 69 (argument of plaintiff's counsel).

10729 Mass. (12 Pick.) at 70. 
so situated, that it could not be beneficially used without the aid of this power."108 However artificial it may have been in the existing context, Shaw argued that the mill act "was designed to provide for the most useful and beneficial occupation and enjoyment of natural streams and water-courses, where the absolute right of each proprietor, to use his own land and water privileges, at his own pleasure, cannot be fully enjoyed, and one must of necessity, in some degree, yield to the other." 109

In spite of the difficulties inherent in viewing the mill act as a mere regulation of water rights, Shaw preferred to rest at least part of his case on that restrictive but historically approved function. Thus, he put great emphasis on the relativity of rights as between riparian owners while minimizing his reliance on a theory of eminent domain. This effort to limit the importance of the power of eminent domain appears to reflect a growing realization of the essentially private nature of the interests that were being served by the mill acts and a consequent unwillingness to allow the state to intervene solely to advance private ends. ${ }^{110}$

Although it did help to overcome some of the difficulties in applying a theory of eminent domain to essentially private activities, the main contribution of Shaw's formulation was to force courts to see that a conception of absolute and exclusive dominion over property was incompatible with the needs of industrial development. Whether the rationale for state intervention was eminent domain or a more explicit recognition of the relativity of property rights, however, under the influence of the mill acts men had come to regard property as an instrumental value in the service of the paramount goal of promoting economic growth.

108 Id. at $70-71$.

$100 I d$. at 71-72. At a later date, we have seen, in a strictly common law action dealing with the right of riparian owners to the use of water, he extended this concept still further in the interest of promoting economic development, by suggesting that where a stream could satisfy the full power needs of only one manufacturer, the law would encourage this monopoly by recognizing an exclusive right in the first appropriator-this time, without compensation. Cary v. Daniels, 49 Mass. (8 Met.) 466 (1844).

$110 \mathrm{He}$ was not successful in carrying the court with him. In the same year, when Shaw was not sitting, the Massachusetts Supreme Court rested the entire case for the mill acts on an expansive conception of the power of eminent domain. Boston \& Roxbury Mill Dam Corp. v. Newman, 29 Mass. (12 Pick.) 467 (1832). Shaw himself on occasion reverted to a "pure" eminent domain theory. Hazen v. Essex Co., 66 Mass. (12 Cush.) 475, 477-78 (1853); cf. Chase v. Sutton Mfg. Co., 58 Mass. (4 Cush.) 152, $169-70$ (1849). Yet, clearly troubled by this rationale, he declared in 1851 that " $[t]$ he principle on which the law is founded is not, as has sometimes been supposed, the right of eminent domain. . . . It is not in any proper sense a taking of property of an owner of the land flowed, nor is any compensation awarded by the public." Murdock v. Stickney, 62 Mass. (8 Cush.) 113, 116 (1851). 


\section{The Problem of Improvements}

From the beginning of the nineteenth century, judges, faced with the perplexing problem of adjusting the law of property to a theory of value based on the productive capacity of land, were forced at every turn to deal with two central facts about the American economy. First, there was a consistent pattern of speculation and rising land prices. Second, the value of land was often intimately related to the value of the improvements on it. In hundreds of cases, courts were faced with the question whether the common law rules, premised on a preproductive conception of land and promulgated in an economy in which the price of land had remained relatively constant, should be applied to an economy of rapidly fluctuating land prices and an increasing rate of development.

\section{A. "What would in England be waste"}

The English law of waste was relatively clear: any fundamental alteration by a tenant of the condition of the land constituted waste for which he was liable. Glearly, however, an economy dependent on clearing land for economic development could not enforce a rule of maintaining the existing condition of land. From the moment of independence from England, therefore, American jurists devoted their efforts to modifying or overturning the received common law doctrine.

Writing in 1801, James Sullivan acknowledged the existence of the strict English rules governing waste, but maintained that "we have no reports or recollections of their being adopted here. The situation of our country is so very different, in point of agriculture, from what they are in Europe, that we hardly know how to apply the precedents there to our cases." Indeed, Sullivan continued, since leases were "generally for a short space of time" and since "the nature of the soil and the manner of improvement" were different, there were in America "few occasions for actions of waste."111 Similarly, Zephaniah Swift of Connecticut believed that "in this country, such conversions in [land use] as are compatible with good husbandry, would not be deemed waste."112

Even so, there remained deep disagreements in the first quarter of the nineteenth century over how far a tenant could go in transforming land for purposes of economic improvement. In New York, for example,

$111 \mathrm{~J}$. Sulurvan, supra note 11 at 334-35.

1122 Z. SwIFT, supra note 8 at 82. Similarly, in 1801 the Pennsylvania Supreme Court refused to allow an action of waste against a tenant in dower. "It would be an outrage on common sense," the court stated, "to suppose that what would be deemed waste in England, could receive that appellation here. Lands in general with us are enhanced by being cleared, provided a proper proportion of woodland is preserved for the maintenance of the place." Hastings v. Crunkleton, 3 Yeates 261, 262 (Pa. 1801). 
the Supreme Court divided sharply in an action by a landowner whose 133-acre farm was "wild and uncultivated, and covered throughout with a forest of heavy timber" when his tenant took possession. The tenant had cleared most of the farm and cut down and removed the timber. Acknowledging that "what would in England be waste, is not always so here," the court nevertheless held that the tenant had forfeited the estate through waste. Though he "undoubtedly had a right to fell part of the timber, so as to fit the land for cultivation," he did not have a right to "destroy all the timber, and thereby essentially and permanently diminish the value of the inheritance."113 The dissenting minority wanted to go still farther in changing the law to suit the necessities of development. Justice Ambrose Spencer argued that "the doctrine of waste, as understood in England, is inapplicable to a new unsettled country. ... [M]en differ very widely as to how much woodland ought to be left for the use of a farm." Without a covenant between the parties "to leave a sufficient quantity of land in wood ... we have no right to say some waste might be committed, and other waste might not ...." Spencer was, in effect, denying that the law of waste was an inherent part of the right to property, since the only basis for judicial prevention of waste, in his view, was a contract between the parties. ${ }^{114}$

No American court was willing to go as far as Spencer would have, severing entirely the right to property from the right to prevent tenants from completely altering the estate. No American court, however, enforced the strict English common law governing waste. Some, like New York, modified it, while others rejected it wholesale. ${ }^{115}$

An important aspect of the American redefinition of the law of waste dealt with the common problem of improvements. It was clear at

113 Jackson v. Brownson, 7 Johns, 227, 232 (N.Y, 1810) (emphasis in original).

$114 I d$. at 236. Some may regard this conclusion as too extreme. Jackson v. Brownson was an action for forfeiture of the tenancy due to breach of the covenant against waste. "If this was an action of covenant to recover damages." Spencer conceded, "then, indeed, we should have a right to give the covenant not to commit waste a greater latitude of construction." $I d$. While it is true that he would have relaxed his reluctance to find waste were the consequences less grave than forfeiture, still this conclusion was based on contract principles and not on a theory of a right to prevent waste inherent in the ownership of land.

115 See, e.g., Findlay v. Smith, 20 Va. (6 Munf.) 134, 142 (1818), in which the court refused to find waste on the ground that "the law of waste, in its application here, varies and accomodates itself to the situation of our new and unsettled country." "England is an old country," wrote Dane in 1824, "where trees are raised even for fuel by planting and industry, almost as much as corn or grain is. This is a new country, where, except in some parts, of late years, the great object has been to destroy trees, to clear up the land, and to bring the wilderness or natural forests into cleared lands for cultivation and pasturing ...." $3 \mathrm{~N}$. DANe, supra note 11, at 214. See also 1 W. Crurse, A Drgest of THE LAw of Real. Property 116 n.2 (Greenleaf ed. 1849). 
common law that a tenant who erected buildings on land had no right to remove them at the end of his term. During the eighteenth century, English courts had established an exception for the removal of fixtures that were built to carry on a trade, but they made no such concession for buildings erected solely for agricultural purposes. ${ }^{116}$ In Van Ness $v$. Pacard, ${ }^{117}$ Justice Story expressed the already established view ${ }^{118}$ that the common law rule had never been received in America.

The country was a wilderness, and the universal policy was to procure its cultivation and improvement. The owner of the soil as well as the public, had every motive to encourage the tenant to devote himself to agriculture, and to favour any erections which should aid this result; yet, in the comparative poverty of the country, what tenant could afford to erect fixtures of much expense or value, if he was to lose his whole interest therein by the very act of erection?119

Although, technically, $\operatorname{Van}$ Ness held only that the fixtures in question were in fact trade fixtures and thus still within the English exception, Story's decision was, as Chancellor Kent observed, part of "a system of judicial legislation" that had "grown up . . . so as to almost render the right of removal of fixtures a general rule, instead of being an exception." 120 Indeed, Kent maintained that extension of the rule to agricultural fixtures "may be necessary for the beneficial enjoyment of the estate" since it would encourage the tenant "to cultivate and improve" the land.121

\section{B. "Waste of the inheritance"}

The policy of promoting improvements was not always easy to apply. One of the most complicated departures from English law involved the right of widows to dower in unimproved land or land that was improved after the widow's husband had sold it. Most states in the nineteenth century continued to enforce some version of the common law rule that a widow was entitled to a life interest in one-third of the land held by her husband during their marriage. And, since a husband could not be allowed to defeat the dower right of his wife by transfer-

116 See Elwes v. Maw, 3 East 38 (K.B. 1802).

11727 U.S. (2 Pet.) 137 (1829).

118 The most important prior decisions are Whiting v. Brastow, 21 Mass. (4 Pick.) 810 (1826), and Holmes v. Tremper, 20 Johns. 29, 30 (N.Y. 1822), which distinguishes Elwes v. Maw, 3 East 38 (K.B. 1802), as inapplicable to less than major constructions.

11927 U.S. (2 Pet.) at 145.

$1202 \mathrm{~J}$. Kent, Commentaries 343 (3d ed. 1836). In the first two editions of the Commentaries Kent had merely repeated the conventional English view. The author of Fixtures, 10 AM. JURIST 53, 56 (1833), states that the distinction between trade and agricultural fixtures "does not seem to have been generally admitted to prevail" in America.

$1212 \mathrm{~J}$. Kent, Commentaries 346 (3d ed. 1836). 
ring the land, in most states she could enforce this right against a purchaser of the property from her husband.

Because the value of land was increasingly determined by its productive capacity, American courts had to decide whether to follow the common law in measuring dower by the value of land divorced from its productive capacity. This issue arose in several different forms. Did unimproved lands have any greater value for purposes of measuring dower if they could be sold to speculators for a substantial price? Would the dower right be computed on the basis of existing rents and profits if speculation had raised the land's market price above any sum that could reflect its present productivity? That is, was a widow entitled, as at common law, to a life interest in one-third of the land or only to a one-third interest in the profits? Finally, how would dower be computed on land that a husband had sold in his lifetime and that, by the time of his death, had increased in value, either because of a general rise in land values or because the purchaser had improved it?

The courts wrestled with each of these questions from the beginning of the nineteenth century. In 1783, an unreported Massachusetts decision $^{122}$ had turned back a challenge to the common law rule that a widow was entitled to dower in unimproved lands. The first clear change in the theory of land valuation appears in Leonard v. Leonard. ${ }^{123}$ Commissioners appointed by the probate judge had appraised the relevant real estate, "a considerable part of which was woodland and unproductive." The widow was awarded land valued at one-third of the total, though it was agreed that her actual share "comprised the most productive parts of the . . . estate." Reversing and holding that dower should be determined not by the market value but by the rents and profits of the estate, the court declared: "This rule is adapted equally to protect widows from having an unproductive part of estates assigned to them, and to guard heirs from being left, during the life of the widow without the means of support."

This rule may have appeared to be even-handed when it was announced, but in a speculative and developing economy, with the market value of land consistently above the capitalized value of its present product, dowagers would soon become victims of the theory underlying it. In Conner v. Shepard, ${ }^{124}$ the Supreme Judicial Court carried the new rule of Leonard to its logical conclusion. Overruling its decision of thirty-five years earlier, the court denied a widow's claim to dower in

122 Nash v. Boltwood (1783) in W. Cushing supra note 10. A report of the decision was first published in J. STORY, supra note 74 at 366 (1805).

1234 Mass. 533 (1808).

12415 Mass. 164 (1818). 
unimproved lands. Since dower is to be measured by the productive value of the land, Chief Justice Parker reasoned, there could be no dower in unimproved lands. Could not the widow, if only given her traditional share, herself make the lands productive? No, said the court, for that would constitute waste. Returning for this particular situation to the discredited common law doctrine of waste, the court declared:

[A]ccording to the principles of the common law, her estate would be forfeited if she were to cut down any of the trees valuable as timber. It would seem too that the mere change of the property from wilderness to arable or pasture land ... might be considered waste: for the alteration of the property, even if it became thereby more valuable, would subject the estate in dower to forfeiture: the heir having a right to the inheritance, in the same character as it was left by the ancestor. ${ }^{125}$

Thus, the widow lost either way. A utilitarian standard of value made worthless her dower rights in unimproved lands, while a nonutilitarian rule of waste made improvement impossible.

The contradictions go deeper still. In order not to rest the argument from waste entirely on outmoded rules of common law, Parker went on to argue that improvements by a tenant in dower "would be actually, as well as technically, waste of the inheritance." "[L]ands actually in a state of nature may," he said, "in a country fast increasing in its population, be more valuable than the same land would be with ... cultivation ...." ${ }^{126}$ Parker here seemed to be suggesting that legal rules should be used to discourage and delay economic improvement as long as buyers were willing to pay more for undeveloped than for developed land. If so, his theory appears to be without support in other cases, and inconsistent with the conception of property then emerging in the case law. ${ }^{127}$ Indeed, the premise that underlay the changing law of waste was that it was preferable to encourage immediate improvement by tenants, even at the risk that development might prevent other future uses and thereby impair the transferability of land.128

125 Id. at 167 (emphasis added).

128 Id.

127 See 3 N. DANE, supra note 11, at 219.

128 There is, however, another more general hypothesis that could explain Parker's support for the view that immediate development would make land less valuable. Land speculation was one of the most important businesses in postrevolutionary America. "Judges, land officers, government officials and their families, and military officers, jumped in at the very beginning of their residencies in new territories to acquire claims." P. Gates, History of Public Land Law 92 (1968). Many territorial judges were involved in land speculation, and there were many cases of judicially sanctioned land frauds. A large part of the legal profession was also involved in speculating in land. A. ChandLer, Land Title Origins 484 (1945); M. Rohrbough, The Land Office Business 21 (1968). 
The conclusion seems inescapable that Parker's central purpose in Conner $v$. Shepard was to undermine the right of dower itself. "[B]elieving that [the dower right] would operate as a clog, upon estates, designed to be the subject of transfer," the court was prepared to use any method to cut off the widow's share, including reliance on dubious assumptions about the relation between market price and productive value. Perhaps the most important effect of the holding that a widow was not entitled to dower in unimproved lands, however, was to promote further the view that the value of land was exclusively a function of its productivity.

The doctrine of Conner $v$. Shepard was clearly an exception to a general policy of encouraging improvements by those in possession of land. That policy was most uniformly pursued in the related context of dower rights asserted against purchasers rather than heirs. For example, from the first decade of the nineteenth century, the Massachusetts courts had held that a widow could not receive any of the increase in the value of land owing to improvements made by her husband's vendee. ${ }^{129}$ Identical results were reached in all the other states. ${ }^{130} \mathrm{New}$ York, moreover, held that a widow could not gain the advantage either of improvements or of a general increase in land values. ${ }^{131}$ On the other hand, the Supreme Court of Pennsylvania, which as early as 1792 had denied that dower extended to improvements, ${ }^{132}$ refused to deprive the widow of the benefit of general increases in land values. ${ }^{133}$ While courts thus divided over who should have the benefit of increasing land prices, they all agreed that-regardless of common law property doctrines-the value of improvements should be left with the developer.

The historical literature on government land policies emphasizes the disastrous consequences of governmental encouragement of speculation. "Men coming into a new community were regarded as intruders who would seriously retard the growth of the area for years by withholding land from development while they waited for its value to rise." P. Gates, supra, at 149. In short, Parker's opinion may reflect a more general pro-speculative and antidevelopmental legal ideology that flourished under the doctrine of free transferability of land. See, e.g., Claiborne v. Henderson, I3 Va. (3 Hen. \& Munf.) 322, 331 (1809).

129 Libby v. Swett (1804) in Francis Dana Papers, Mass. Historical Society (Box 15 "Supreme Judicial Court Cases"). Published reports of this case appear in J. STORY, supra note 74, 365 and 4 N. DANE, ABRIDGEMENT 675 (1824). See also Webb v. Townsend, 18 Mass. (1 Pick.) 21 (1822); Ayer v. Spring, 9 Mass. 8 (1812).

130 E.g., Braxton v. Coleman, 9 Va. (5 Call) 433 (1805).

131 Humphrey v. Phinney, 2 Johns. 484 (1807) (improvements); Dorchester v. Coventry, 11 Johns. 510 (1814) (increased land value).

182 Winder v. Little, 1 Yeates 152, 154 (1792).

133 Thompson v. Morrow, 5 S. \& R. 289, 291 (1819). 
C. Gaveat Emptor: "as if the rules of equity, justice, and convenience, were the rules of law"

Perhaps the most perplexing question raised at the end of the eighteenth century by the new judicial emphasis on the productive value of land involved the proper measure of damages for breach of warranty in the sale of land. In most deeds of sale the seller warranted that he had seisin, or good title, in the land; in addition or instead, the seller might insert a covenant guaranteeing the purchaser quiet enjoyment of his land. If the purchaser, after a period of time on the land, was evicted by one proving superior title, would he be able to recover from the seller any increase in the value of the land-due either to intervening improvements or to rising prices-or was he limited to recovery of the purchase price?

Again, the rule of the English common law was clear: the purchaser could recover only the original price he had paid. While some explanations for the English rule harkened back to the mysteries of feudal land law, most American courts that departed from the English view maintained, in the words of the Connecticut Supreme Court, that "the diversity ... between British practice and ours, is undoubtedly founded in the permanent worth of their lands, as an old country, and the increasing worth of ours as a new country." In America, the court added, "it is supposed that the purchaser goes on, improves and makes the land better till he is evicted." 134

By 1810, six states had passed upon the measure of damages for breach of a warranty of title. In four, South Carolina, ${ }^{135}$ Connecticut, ${ }^{136}$ Virginia, ${ }^{137}$ and Massachusetts, ${ }^{138}$ the purchaser was permitted to recover the ordinarily higher value at the time of eviction. In Pennsylvania ${ }^{139}$

134 Horsford v. Wright, 1 Kirby 3 (Conn. 1786).

135 Guerard v. Rivers, 1 Bay 265 (1792); Liber v. Parsons, 1 Bay 18 (1785).

136 Horsford v. Wright, 1 Kirby 3 (1786).

137 Humphrey's Adm'r v. McClenachan's Adm'r, 15 Va. (1 Munf.) 493, 500 (1810); Mills v. Bell, 7 Va. (3 Call) 320, 326-27 (1802). In Lowther v. Commonwealth, 11 Va. (1 Hen. \& Munf.) 201 (1806), a purchaser had recovered the full value of the land at the time of eviction from the seller. The seller then petitioned the state, his grantor, for compensation. The court held that he could only recover his sale price from the state, since in the original suit against him, the measure of damages should have been limited to that sum. Though clearly overruled by Humphrey's Adm'r v. McClenachan's Adm'r, supra, this case was never mentioned.

138 Gore v. Brazier, 3 Mass. 523, 545 (1807). Massachusetts distinguished between breach of covenants of seisin, for which only the purchase price was recoverable, Marston v. Hobbs, 2 Mass. 433, 440 (1807), and breach of covenants of quiet enjoyment for which the value at the time of eviction was recoverable. The theory was that the breach of the former took place before the eviction, while eviction was the cause of the latter breach. 139 Bender v. Fromberger, 4 Dall. 436, 441-46 (Pa. 1806). Although the decision does 
and New York, ${ }^{140}$ he recovered only the purchase price plus interest.

Much of the difference of opinion was said to turn on the intent of the parties to the warranties. Judge Pendleton of South Carolina, in promulgating his state's rule in 1785, declared: "Men do not make purchases, with a view of merely having interest for their money; but they contemplate the rise in value of the thing purchased."141 Pennsylvania and New York, by contrast, looked to the presumed intention of the seller. "I question," wrote Judge Van Ness of New York, "if one [seller] out of ten thousand enters into these covenants with the remotest belief, that he is exposing himself and his posterity to . . . ruinous consequences ...."142 But inevitably, the difference of opinion reflected a difference in the choice of which interests in the population to advance. While Judge Spencer, dissenting from the New York rule allowing only the lower measure of recovery, asked: "[W] hat is to become of the industrious citizen or mechanic, who has spent his hard earnings in erecting his little house or workshop, relying on the covenant in his deed, if he can only get back his purchase-money and interest?"143 Judge Tilghman of Pennsylvania answered that it would be unreasonable to allow the higher measure where "buildings of magnificence are erected to gratify the luxury of the wealthy."144

The story after 1810 is of a return to common law orthodoxy, this time under the aegis of newly emerging theories of contract damages. In both Kentucky and Tennessee-the first western states to rule on the question-the courts limited the recovery of an evicted purchaser to the lower contract price plus interest. The Tennessee court did so while congratulating itself for "a laudable disposition . . . to substitute certainty for uncertainty" in measuring contract damages. ${ }^{145}$ In Kentucky, although the result was much the same, the court first distinguished, as had many of the dower cases, between recovery for the increased value of land and recovery for improvements. Compensation

not mention whether the plaintiff was entitled to interest on the purchase price, the jury had returned damages of $\$ 2,979$ and the purchased price was $\$ 2,390$. Id. at 436 . The court affirmed the verdict. Two Pennsylvania trial court rulings in 1804 and 1806 had previously split on the question of damages. See THE INstitures of JUSTINIAN 619-20 (T. Cooper trans. 1812) (translator's notes). Finding the issue unsettled, a third trial court instruction has apparently requested that the jury return a special verdict, specifying separate damages for the purchase money and the value of improvements. 4 Dall. at 445 (opinion of Smith, J.).

140 Stats v. Ten Eyck, 3 Gai. 111 (1805) (opinion of Livingston, J.) (increased land values); Pitcher v. Livingston, 4 Johns. 1 (1809) (improvements).

141 Liber v. Parsons, 1 Bay 18, 20 (1785).

142 Pitcher v. Livingston, 4 Johns. 1, 11-12 (1809).

$143 I d$. at 14.

144 Bender v. Fromberger, 4 Dall. 436, 444 ( $\mathrm{Pa}$. 1806) (emphasis in original).

145 Talbot v. Bedford's Heirs, 3 Tenn. 447, 455 (1813). 
for loss of increased land values, it concluded, could not have been contemplated by the parties, since it represented only "a bare possible hypothetical loss." Improvements, however, were a different matter. Nevertheless, since the legislature had already passed a statute allowing a good faith purchaser to recover the value of his improvements from one who, with superior title, had ousted him, he would not be allowed to recover against the seller as well. ${ }^{148}$

By 1815, North and South Carolina had also adopted the common law rule, ${ }^{147}$ the latter having abandoned its prior decisions in favor of purchasers. Virginia reversed its position soon thereafter. ${ }^{148}$ The result was that only in Massachusetts and Connecticut could a purchaser recover the increased value of the land at the time of eviction; in these states he could do so only under a covenant of quiet enjoyment, and not under a warranty of good title. ${ }^{149}$

The majority damage rule for breach of a warranty of title soon became a prominent target of a growing legal literature extolling the virtues of the civil law. Thomas Cooper of South Carolina, who published an annotated translation of the civilians' bible, the Institutes of Justinian, correctly saw the warranty decision as part of a movement to extend the rule of caveat emptor, which he denounced as "a disgrace to the law" and a most "comfortable doctrine for the land-jobbers."150 And in a letter to William Sampson, who was something of a patron saint among the civilians, Charles Watts of New Orleans sang the praises of Louisiana's civil law and denounced caveat emptor for depriving innocent purchasers of the value of their improvements. ${ }^{151}$ Watts elaborated on Cooper's contention that the rule limiting sellers' liability favored the interests of land speculators, who were, after the national government, the principal vendors of unsettled lands. His emphasis on the disparity of legal and economic knowledge disfavoring buyers underlined the view that caveat emptor had political and distributional consequences that could not be dismissed with a complacent assertion that the parties were free to alter them by contract.

The contract conception of land warranties, which became dominant

146 Cox's Heirs v. Strode, 5 Ky. 273, 278-79 (1811).

147 Phillips v. Smith, I Carolina Law Repostrory 475 (N.C. 1814); Furman v. Elmore, 2 Nott \& McC. 189, 198-204 (S.C. 1812).

148 In Stout v. Jackson, 23 Va. (2 Ran.) 132 (1823), a divided court limited recovery to the purchase price plus interest, but it was only in Threlkeld's Adm'r v. Fitzhugh, 29 Va. (2 Leigh) 451 (1830) that the earlier rule was finally abandoned.

149 See note 138 supra.

150 The Institutes of Justinian 610, 620 (Cooper trans. 1812) (translator's notes).

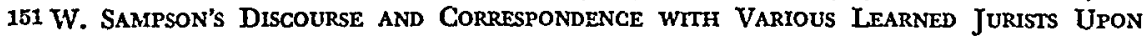
THE HISTORY OF THE LAw 78 (Thompson ed. 1826). The date of the letter is not given, but it was clearly written between 1823 and 1826 . 
after 1810, had some surprising consequences. Though it is conventional to view the effect of nineteenth century rules of contract damages as placing the injured party in the position he would have occupied had the contract been performed, the result was everywhere the opposite in the case of warranties of title..$^{162}$ The rule limiting warranty damages to the purchase price seems inconsistent with a dominant theme of the period-the use of legal rules to promote improvements by assuring to developers the benefits of their investments. It may, in fact, be a prominent example of the negative influence of land speculation on the course of American legal doctrine. ${ }^{153}$ On closer inspection, however, one finds that the policy of promoting improvements was accomplished mainly in another way, by means of "good faith possession" statutes. These statutes enabled a bona fide purchaser of land to recover the value of his improvements from one who, with superior title, ousted him from possession. While this approach had the merit of forcing the actual beneficiary of the "unjust enrichment" to disgorge the value of improvements, it also forced him to take the improvements whether he wished to or not. The value of the improvements, as Chancellor Kent lamented, "may have been very costly, and beyond the ability of the claimant to refund ...." And, appealing to traditional conceptions of property, he emphasized that the claimant might "have a just affection for the property, and it might have answered all his wants and means in its original state, without improvements." 154

Legislative schemes to protect the value of improvements were widely adopted during the first half of the nineteenth century. ${ }^{155}$ In the western states, where land titles were in great disarray, statutory intervention was essential to assure to landowners the minimum security required for development. These statutes, which threw the risk of bad title entirely on the innocent nonoccupying owner, probably also had the effect of neutralizing political pressure to put the risk on land speculating sellers. The Kentucky "Occupying Claimant" law, adopted shortly after Kentucky became independent of Virginia, was said to have been enacted because "there existed . . . claims to more than three times the quantity of the lands" in the state. ${ }^{156}$ When the

152 See, e.g., the contractarian reasoning of the Tennessee and Kentucky courts in Talbot v. Bedford's Heirs, 3 Tenn. 447, 454-55 (1813) and Cox's Heirs v. Strode, $5 \mathrm{Ky} .273$, 278-79 (1811).

153 See note 128 supra.

1542 J. Kent Commentarifs 336-37 (4th ed. 1840).

165 For the Massachusetts statute of 1807, see Improvements on Land, 2 AM. JURIST 294 (1829), which is largely devoted to establishing the civil law pedigree of the statute.

150 Message of the Governor of Kentucky Transmitting to the General Assembly the Report of Henry Clay and John Rowan Together With the Petition Presented by Them to 
United States Supreme Court invalidated the law as an interference with the obligation of contract, ${ }^{157}$ it sent a wave of apprehension throughout the states that all these acts might be voided.

Chancellor Kent lent the authority of his Commentaries against these statutes as well. He conceded that "peculiar and pressing circumstances" existed in many states because "the titles to such lands had, in many cases, become exceedingly obscure and difficult to be ascertained, by reason of conflicting locations, and a course of fraudulent and desperate speculation." Yet he argued that the statutes were "strictly encroachments upon the rights of property," and concluded that "such indulgences are unnecessary and pernicious, and invite to careless intrusions upon the property of others." 158 Following Kent's views, the Supreme Court of Tennessee in 1830 declared that state's occupying claimant statute "subversive of the clearest principles of natural right in relation to property, and consequently, of the constitution, which guarantees to every man the exclusive use of his own property."'150 There was no further federal constitutional challenge to these laws, however, and by the time that Kent published the third edition of his Commentaries in 1836, most states had enacted some form of statutory protection for good faith improvements made by purchasers. ${ }^{160}$

the Supreme Court of the United States for a Re-Hearing of the Case Involving the Validity of the Occupying Glaimant Laws 12 (1823).

157 Green v. Biddle, 21 U.S. (8 Wheat.) 1 (1823). The Court had first decided against the statute in 1821, Justice Story writing a short, unsatisfactory opinion. The case was reargued in 1822, with Justice Washington the next year writing a more elaborate opinion striking the law down. Justice Johnson wrote a brilliant opinion upholding the constitutionality of the statute, though on the basis of a procedural point he formally concurred with the majority. 2 C. WArRen, The Supreme Court in United STAtes History 96-102 (1926).

158 2 J. KENT, CoMmentartes *337-38 (4th ed. 1840).

150 Nelson v. Allen, 9 Tenn. 360, 379 (1830). In the third edition of his Commentaries (1836), Kent cited Nelson v. Allen for this proposition. 2 Commentaries 335 n.(d). However, Judge Catron, who also participated in the decision, added a note to the report of the case, which stated that he regarded "the examination of the constitutional question" as "gratuitous in this cause." 9 Tenn. at 386. Even Kent acknowledged that the case allowed the good faith occupant to recover the value of his improvements in a separate suit in equity. 2 Commentaries $336 \mathrm{n}$.(c). The full opinion in Nelson seems to deny the validity of even that procedure, 9 Tenn. at 380, 383-84, although Judge Catron's note clearly permits it. $I d$. at 386 .

$1602 \mathrm{~J}$. Kent, Commentaries 336 (4th ed. 1840) lists eight states as having a statute. I have also added the limited New York statute discussed by Kent, id. at 335, and the Tennessee statute, see note 159 supra. In the twelfth edition of Kent's Commentaries, Oliver Wendell Holmes Jr. stated that the principle of protecting good faith purchases had "been adopted very generally by the courts or legislatures of the several States." 2 J. KeNT, CoMmentaries, 336 n.(1) (O. Holmes ed. 1873). 


\section{CONCLUSION}

The American conception of property in the period between the Revolution and the Civil War was changed to permit the destruction of older forms of property by newer agents of economic development. In the process of change, land came to be viewed almost exclusively as a productive asset, and ownership of property was justified not for its own sake but for its contribution to increased national wealth. Legal doctrines, in turn, were transformed by this instrumental conception of property. At the beginning of the century, property law tended to encourage high risk investment through a doctrine of priority, which conferred exclusive property rights on the first developer. By the middle of the century, however, the law had shifted to a reasonable use or balancing test which allowed newer entrants to compete while destroying the claims that existing property owners had acquired under older legal doctrines. In the process of responding to the changing and often unstable utilitarian standard of efficiency, the American conception of property was harnessed to the paramount goal of economic development. 